\title{
CITIZENSHIP ACTS: QUEER MIGRANTS AND THE NEGOTIATION OF IDENTITY AND BELONGING AT TORONTO PRIDE WEEK 2009
}

$$
\text { by }
$$

Johannah May Black

BAH, Acadia University, 2007

A Major Research Paper presented to Ryerson University

in partial fulfillment of the requirements for the degree of

Master of Arts

in the Program of

Immigration and Settlement Studies

Toronto, Ontario, Canada, 2009

(C) Johannah May Black 2009 


\section{Author's Declaration}

I hereby declare that I am the sole author of this major research paper.

I authorize Ryerson University to lend this paper to other institutions or individuals for the purpose of scholarly research.

1 Iurtner aumorize kyerson university to reproduce this paper by photocopying or by other means, in total or in part, at the request of other institutions or individuals for the purpose of scholarly research. 


\title{
CITIZENSHIP ACTS: QUEER MIGRANTS AND THE NEGOTIATION OF IDENTITY AND BELONGING AT TORONTO PRIDE WEEK 2009
}

\author{
Johannah May Black \\ Master of Arts, 2009 \\ Immigration and Settlement Studies \\ Ryerson University
}

\begin{abstract}
The broader goal of this research is apply queer theory to the cultural narrative of migration in order to confuse, destabilize and complicate our pre-conceived notions about what it means to "belong" to a given community or society, what it means to cross borders, and what it means to be(come) "Canadian". Drawing on the notion of "cultural citizenship", this research will focus on the politics of belonging that are embedded in the spectacle of Toronto Pride Week 2009, as a prominent site of negotiation for queer migrant identities. In order to get at a more nuanced and complicated understanding of integration, this research will also be centered around the subjective life experience of Luka, a queer migrant who is also a performer at Pride Week. Luka's performance will be discussed as a liminal space, which points to multiple ambivalences, and thus acts to challenge the discourse of identity and belonging.
\end{abstract}

Keywords: Queer Migrants, Performative Identity, Cultural Citizenship, Pride Week, Toronto 


\section{ACKNOWLEDGEMENTS}

Thank you to Dr. Doreen Fumia for all of the support, guidance, and advice. Your encouragement and mentorship have been invaluable and have made my year in this program truly worthwhile. Thank you for treating me with such kindness and for taking the time to help me talk through the arguments and ideas that went on to shape this MRP.

Thanks also to my second reader, Dr. Alan Sears for his advice and input, as well as, my professor, Dr. Cheryl Teelucksingh for her encouragement.

Thanks also to Dr. Fiona Whittington-Walsh for her advice on anti-oppressive interviewing methodologies.

Most importantly, thank you to Luka, without whom this MRP would have been impossible. Thank you for trusting me with your stories, insights, and ideas. Your contribution to this MRP and to the knowledge that we have created together has been truly valuable. Your performances, art, and activism remain a source of inspiration to myself and other queer youth in Toronto. 


\section{TABLE OF CONTENTS}

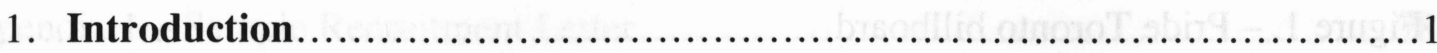

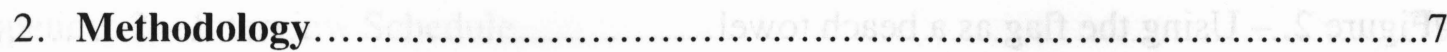

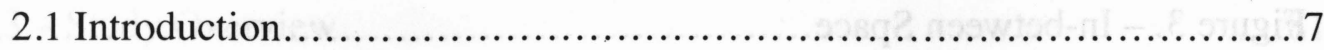

2.2 Research Objective.................................................. 8

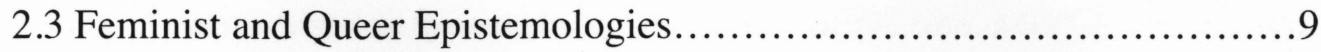

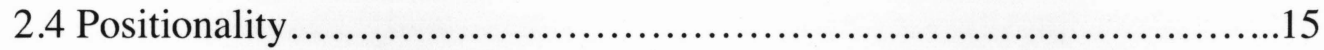

2.5 Feminist and Queer Interview Methodologies and Ethics.................18

2.6 Conclusion and Discussion..........................................

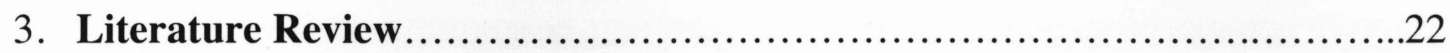

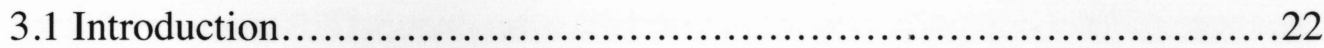

3.2 Cultural Citizenship, Belonging and the "Two-Way Street"..............22

3.3 Performative Identity, Performative Community.....................27

3.4 Subversive Performance, Subversive Bodies............................36

3.5 Conclusion and Discussion..........................................46

4. Pride Week 2009 and the Politics of Belonging .............................47

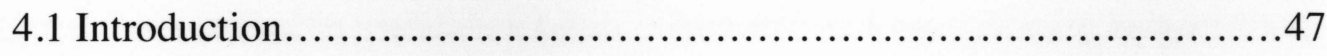

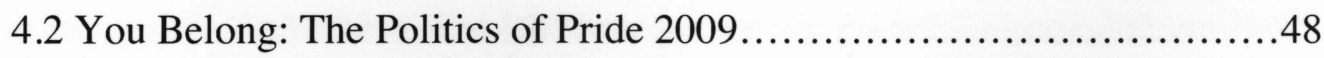

4.3 Breaking the Fourth Wall: Ambivalent Performance and Performative

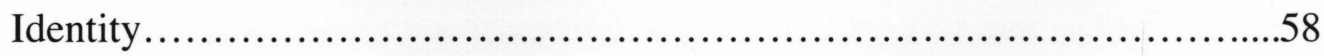

4.4 Conclusion and Discussion....................................... 72

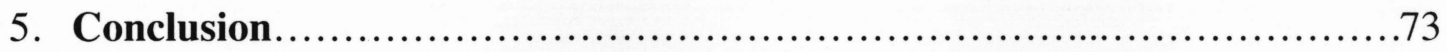

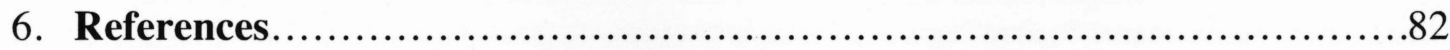




\section{LIST OF FIGURES}

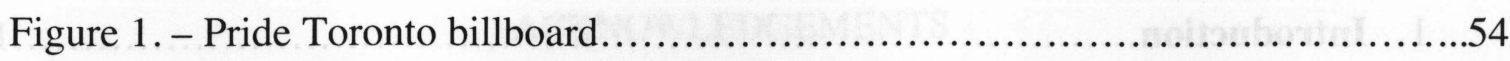

Figure 2. - Using the flag as a beach towel..........................................67

Figure 3. - In-between Space..................................................... 70 


\section{LIST OF APPENDICES}

Appendix 1 - Sample Recruitment Letter..............................................78

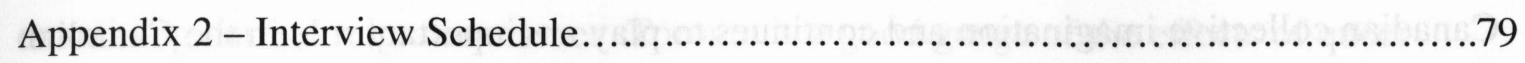

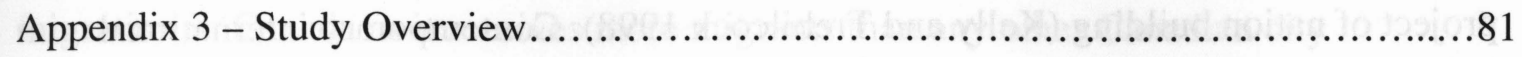




\section{Introduction}

A romanticized narrative of immigration has always occupied a major part of the

Canadian collective imagination and continues to play an important role in the Canadian project of nation building (Kelly and Trebilcock 1998). Contemporary international migration trends; however, have led to what some scholars have dubbed as, "the age of migration" (Castles and Miller 2003). A proliferation of books and articles has been written about the various effects of contemporary immigration flows in Canada. Annual conferences and organizations like CERIS and Metropolis have explored issues of immigration in a joint academic and policy setting' ${ }^{1}$ Scholars have chosen to focus on different groups of migrants, bringing to light their unique stories and examining the nuances of becoming Canadian for migrants who occupy different racialized, classed, or gendered subject positions. Yet, in a country with relatively liberal laws surrounding homosexuality and same-sex desire and one of a few countries that recognizes same-sex marriages, surprisingly little has been written on the experiences of queer migrants ${ }^{2}$ in a Canadian context. As Eithne Luibhéid (2008) observes, "most scholarship, policymaking, service provision, activism, and cultural work remains organized around the premise that migrants are heterosexuals... and queers are citizens (even though secondclass ones) [...so,] where do queer migrants [fit] in?" (169). In Toronto, the occurrence of

\footnotetext{
${ }^{1}$ See http://canada.metropolis.net/ and http://ceris.metropolis.net/. (Accessed 08/18/09).

${ }^{2}$ The term "queer" is used here to refer to a wide range of sexual and gender identities that do not fit within the heterosexual mainstream and to acknowledge the fluidity and ambivalence of these identities. The term "migrant" has also been purposefully used to avoid making distinctions between legal immigrants, nonstatus immigrants, refugees, asylum seekers, and (temporary) foreign workers. As Luibhéid (2008) argues, "such distinctions are less reflections of empirically verifiable differences among queer migrants, who often shift from one category to another, than techniques of nation-state power that remain centrally implicated in neocolonial hierarchies and that classify migrants in order to delimit the rights that they will have or be denied, and the forms of surveillance, discipline, normalization, and exploitation to which they will be subjected" (186).
} 
lawyers, settlement services, and social groups especially serving queer migrants ${ }^{3}$ means that not only do queer migrants exist, but also that their presence is noteworthy in examining current migration issues. Toronto is a good gauge of the effects of queer migration in Canada as it receives more migrants than any other Canadian city (Citizenship and Immigration Canada 2009) and, at the same time, is home to Canada's largest gay village.

Within Canada the debate surrounding the social and cultural integration of migrants has become a significant area of interest for both academics and policy makers (Biles et. al 2008). Separated from the concept of naturalization, whereby migrants receive legal citizenship rights and status, integration focuses on a broader sense of belonging to the nation-state. The study of social and cultural integration considers subjective feelings of belonging, as well as hegemonic power structures that police the social and cultural boundaries of the nation, allowing some to be recognized as citizens and others as outsiders. As Fehér and Heller (1994) argue, becoming acceptable as a citizen has little to do with naturalization and much more to do with processes of cultural adaptation. However, these processes are embedded in power relations where the dominant group, in an effort to maintain its dominance and recreate existing class structures, imposes its culture on, not only migrants but other minorities as well (Bourdieu 1984). If migrant integration is to be understood as anything more than a unilateral imposition of power, then it is necessary to expand typical conceptualizations of integration to include cultural, social, and discursive challenges to mainstream society

\footnotetext{
${ }^{3}$ Settlement services for queer migrants in Toronto include: Supporting Our Youth (SOY) Toronto's Express program, Asian Community Aids Services (ACAS) Settlement program, The 519 Community Center's Among Friends program, Griffin Centre's ReachOUT program and CultureLink's Newcomer Pride program.
} 
and culture. In this sense, integration is a much larger project than the status of migrants. It is a democratic project that can be extended to include the status of ethnic and racial minorities, the status of women, the status of disabled people, and the status of LGBT (lesbians, gays, bisexuals, and transgendered) people among others. This is because migrants necessarily occupy racialized, gendered, sexualized and other class-based subjectivities that are interlocking with their migrant subject-position.

Several scholars have persuasively argued that the crucial project of integration begins at the lowest geographical levels, in the city (Anisef and Lanphier 2003; Florida 2005; Kiel and Hubner 2005) and even the neighbourhood or community (Castles 2002; Guo 2008; Yuval Davis 1999). For queer migrants, that this process may begin in queer communities is suggested by three of the five main settlement services for queer migrants in Toronto having emerged from existing queer community organizations ${ }^{4}$. Some scholars have presented a romanticized version of the integration narrative, arguing that queer migrants, othered by their deviant sexualities, will naturally fit into their new queer sub-culture where they will immediately feel at home (Sinfield 2000). Integral to this conception is a romanticized re-imagining of the existing queer groups, networks, and scenes, as a singular and cohesive community that strongly resembles the imagined unity of the nation (Wray 2000; Frolic 2001). This study will draw on queer theory to develop a post-structuralist critique of simplistic comprehensions of integration, arguing that belonging is inextricably intertwined with identity and therefore operates in a much more insidious and convoluted manner than suggested by most understandings of integration. It will also be argued that although queer politics represent a counter-cultural force, as a

\footnotetext{
${ }^{4}$ SOY, ACAS, and The 519 Community Centre were all pre-existing queer community organizations before they expanded their mandate to include settlement services for queer migrants.
} 
network of groups fighting for social and cultural integration in its own right, many of the same hegemonic forces found in broader society are recreated within queer communities. This creates a mainstream queer culture and society that queer migrants must negotiate. In particular, the politics of solidarity, associated with the "Queer Nation" movement of the 1990s, as well as the fight for same-sex marriage rights and a respectable, middleclass, domesticated "way of life" in the early 2000s, have left behind a legacy of power imbalances and oppression. These politics act to maintain the fixed boundaries of the queer community and often exclude queer women, racialized queer people, trans people, poor queer people, disabled queer people and others who are minoritized both in the queer community and within broader society (Chang Hall 1993; Butler 2004). In arguing this, the simple narrative of queer migrants moving into a queer home will be challenged.

Before outlining the scope and the goals of this project, it is first necessary to clarify my use of the word "queer". When I speak of "gay" and/or "lesbian" communities or identities, I am speaking of communities and identities that are necessarily bounded. These identities and communities are always non-inclusive in their bounding and in their dependence upon heterosexuality to constitute their difference. This is very similar to the ways that, according to Fanon (1967), the colonizer and the colonized mutually constitute each other's identities. Just as black, post-colonialist scholars such as Stuart Hall (1992; 1996), Paul Gilroy $(1993 ; 2000)$ and Kobena Mercer $(1994 ; 1996)$ have argued for a complicated understanding of racial identities, queer theorists have argued for an understanding of sexuality and gender that is fluid, one which confuses identity constructs and is independent of heterosexuality. "Queer", which was once a term of homophobic abuse, has been reappropriated to symbolize that struggle in the politics and 
academics of sexuality that is post-structuralist. As McKenzie Wark (1997) states, "If we are talking about queerness as a sexuality then let's sexualize the terms: if there is a point to queerness it is to fuck with straightness" (6). What Wark is suggesting is that "queer" posseses a more insidious and convoluted meaning than is typically suggested in its substitution for "gay" or "lesbian." "Queer" is symbolic of the fluidity of sexuality and the miscellany of divergent sexualities, even those forms of heterosexuality that are admittedly fluid ${ }^{5}$. Wark (1997) continues by adding that, “... queerness is what escapes or eludes straightness. Sometimes it may even be a matter of escaping or eluding the straightness of gayness too" (6). The "straightness of gayness" to which Wark refers is embedded in the processes of "othering" that valorize certain gay identities over others, constructions of sexual identity that are fixed and bounded, precisely those forces of boundary construction and maintenance that prevent and confound the integration of queer migrants into queer communities by positioning them as outsiders.

Drawing on the notion of "cultural citizenship" (Ong 1993 and 1999; Rosaldo 1994 and 1999) this research will focus on the politics embedded in the public spectacle of Toronto Pride Week 2009, as a prominent site of negotiation for queer migrant identities and belonging. As Andrea Frolic (2001) notes, during Pride Week, "the community puts itself on display" and thus provides a good opportunity to analyze the interplay between queer culture and ideology (282). In order to get at a more nuanced and complicated understanding of integration, this research will also be centered around the

\footnotetext{
${ }^{5}$ I have recently given some thought to what queer heterosexuality would look like and I have concluded that it would be a fluid or "open" form of heterosexuality that does not necessarily conform to the traditional pillars of heterosexuality, i.e. monogamy or traditional gender roles. Queer heterosexuality would not include the heterosexual appropriation of "queer" as label or practice when this appropriation is a fashion statement or a joke.
} 
subjective life experience of $\mathrm{Luka}^{6}$, a queer migrant who is also a performer at Pride Week. As Luibhéid (2008) notes, queer migrants occupy the space of "impossible subjects" with "unrepresentable histories that exceed existing categories" (171). Much of this problem stems from the essentializing and homogenizing discourse within both queer and immigration studies. Drawing from only one interview participant will allow this research to explore ${ }^{7}$ the idiosyncrasies of identity and belonging without relying too heavily on pre-constructed identity categories and pre-existing, often ethnocentric, models and narratives of integration.

Chapter 2 of this major research paper will outline in further detail my methodological choices, as well as the queer and feminist epistemological assumptions that this work is grounded in. Chapter 3 will present a broad review of the relevant literature, pointing out gaps and engaging in relevant debates. This literature review will focus on three main areas of research. The first area of research will be literature on integration, drawn mainly from scholarship in immigration studies. There will be a focus on Aihwa Ong's (1993 and 1999) and Renato Rosaldo's (1994 and 1999) conceptions of "cultural citizenship". The second area of research will be literature on queer, migrant and racialized identity politics, drawn mainly from queer and/or post-colonial scholarship. There will be a focus on Judith Butler's (1990) theory of performative identity. The third area of research will be literature on subversive performance, drawn mainly from queer and immigration studies, as well as, performance and film studies.

\footnotetext{
${ }^{6}$ Luka will be identified only by first name, but will not be masked by a pseudonym. This will be discussed further in the $2^{\text {nd }}$ chapter.

${ }^{7}$ I want to briefly note the troubling presence of colonialist language in academic thought. My other options for wording were: analyze, examine, investigate, probe, inspect, etc... All of these words connote a colonialist, voyeuristic, or Foucauldian surveillance of, or gaze at, an "object" of research. I know this, yet I am unsure of what other language to use.
} 
This section will focus on examples of subversive performance discussing specific strategies used by queer, migrant, and/or racialized performers and will ask the question; what makes a subversive performance?

Chapter 4 will be divided into two parts. The first part will explore both the webs of power that structure identity and belonging within the space of Toronto Pride Week 2009. The second will explore the performances of queer migrants, particularly Luka's performance, as sites of resistance and negotiation that create the space for new queer identities and multiple ways of belonging to emerge. The first section of chapter 4 will rely on data gathered as a participant observer during Toronto Pride Week 2009, paying particular attention to the discourse of Pride Week. The second section will present an analysis of Luka's performance and will be drawn mainly from a series of discussions with Luka, as well as photographs taken at a reenactment of his performance. The final chapter will bring together the main arguments and discussions found in both the literature review and the analyses from chapter 4 to argue for a complicated understanding of identity, belonging and community, and to problematize the traditional narrative of integration.

\section{Methodology}

\subsection{Introduction}

This chapter will introduce the methodological framework guiding my work and will engage in a critical discussion of the feminist and queer epistemologies in which this scholarship is grounded. When I began this work I considered methodology to be a minor, mostly descriptive part of my research. I have increasingly come to consider methodology a vital part of my research, as well as, an essential part of the political 
project associated with creating "queer" knowledge. This chapter will provide a comprehensive and important analysis and defense of my methodological choices, as well as the epistemological assumptions in which they are embedded.

\subsection{Research Objective}

The broader goal of my research is to apply queer theory to the cultural narrative of immigration and integration in order to confuse, destabilize, and complicate our preconceived notions about what it means to "belong" to a given community or society, what it means to cross borders, and what it means to be(come) "Canadian." To accomplish this, my research will focus specifically on the life experience of Luka, a Brazilian youth who migrated to Canada eight years ago. When I was originally designing this research project, I aimed to interview several performers at Pride in order to get a breadth of experiences and identities. I came to realize; however, that in order to gain a nuanced understanding of intersecting identities and community belonging, my research would benefit from a focus on a series of in-depth interviews with one participant. This work will seek to re-conceptualize the migrant integration process, as well as, the dynamics of community, specifically the queer community. This will be accomplished by exploring the ways in which communities are socially bounded, the processes of "othering" that relegate particular identities to the margins of community, and the effects of community boundaries on the construction of identifiable bodies, bodies with identities. Luka's experiences as a "non-artist" performing at Toronto Pride Week 2009 and other queer venues will guide this research in the exercise of knowledgebuilding and act to challenge the dominant cultural narratives surrounding the role of the community in the integration process. 
Rather than hypothesizing what I imagine Luka's experiences to be through a thesis statement, I allow my work to be guided instead by a research question. This is to allow for flexibility and fluidity as my conceptualization of integration becomes increasingly complex, rather than simplified and generalized, by the insidious workings of identity and the multifarious sites of the negotiation that exist in Luka's performances at Pride Week. The overarching question that grounds my research is, whether or not, queer migrants, especially racialized queer migrants, can use cultural performances to negotiate community belonging as part of the integration process? This question can be broken down into two parts. The first part of my research question is: can politically minded performances, focusing on the intersections of queer and migrant and/or racialized identities, act discursively to subvert narrow, socially constructed notions of queer identity? The second part of my question is: can these same performances be understood as acts of "cultural citizenship" that serve to rewrite the borders of the imagined queer community?

\subsection{Feminist and Queer Epistemologies}

Feminist, queer, and post-colonialist scholars have demonstrated the connections between knowledge and power by critiquing positivist epistemologies' inherent reproduction of hetero-patriarchal and colonialist thought (Lorde 1984; Collins 1990;

Alcoff and Porter 1993; Hesse-Biber 2007). A commitment to queer theory also necessarily involves a commitment to the political goals inherent in the reclamation of "queer". In reclaiming "queer," a radical politics of transformation and transgression occurs as a tool of oppression is turned on its head and reclaimed. This reclamation is not only as a source of pride, but significantly as an ambiguous representation of self that 
resists essentialization and restrictiveness in its concomitant fluidity and dynamism. It is necessary then, for queer scholars to be conscious and critical of the ways that conventional positivist epistemologies can act to objectify and dis-empower the subjects of their research. Furthermore, queer scholars should endeavor to transform the epistemic terrain by developing methodological frameworks that resist, as much as possible, oppressive power relations between researcher and the subject(s) of research. As Audre Lorde (1984) insists,

...the master's tools will never dismantle the master's house. They may allow us temporarily to beat him at his own game, but they will never enable us to bring about genuine change (112).

With this thought in mind, "How [does one] write about the oppressed without becoming one of the oppressors?" (Patai 1991, 139). Daphne Patai's crucial question requires constant contemplation and reflexivity throughout the research process. Lorraine Code (1993) argues that, in some ways, developing an "anarchistic epistemology" is beneficial to challenging authoritative knowledge-claims rooted in positivist thought. This work draws on feminist and queer epistemologies that resist the essentialization and reification that leads to the homogenization of groups and the discursive bounding and fixing of identities. These epistemologies also necessarily include the careful analysis of power dynamics between researcher and participant, in order to resist recreating oppressive power structures through the discursive creation of knowledge. Extending the political goals of queer theory to my methodology and providing a careful analysis of the power structures embedded in my work also helps to ground my work in the political.

The valorization of both objectivity and generalizability in positivist thought has been particularly criticized by queer, feminist and post-colonialist scholars. Scholars have 
argued that generalizability is overly simplistic and tends to ignore or wash over differences in favour of a homogeneity that benefits the dominant group (Alcoff and Porter 1993). For example, socially constructed categories like “visible minority”, “Canadian", and "female" relegate identities to fixed and essentialist boxes. Wielding these categories as analytical units without questioning where they come from is to naturalize them, effectively hiding from view the ways that having fixed identity categories is beneficial, even necessary, to the maintenance of oppressive power structures, such as patriarchy (Lorde 1984). Generalizability also risks erasing the agency of the research subject(s) by interpreting behaviour and subjectivity as pre-determined patterns based on social location (Code 1993, 25; Devault and Gross 2007). I would add that, to contravene the objectives of generalizability and to refuse to write the subjects of research as members of homogenous social groups, also contributes to an undermining of the "authority" of positivism, toward an "anarchistic epistemology" (Code 1993, 20).

I have resisted describing Luka until now because I think it is important to do so in Luka's words in order to allow for the complexities of identity to come through and to resist collapsing the person into the identity category. The following quotes describe how Luka identifies:

I identify as a trans-guy $[\ldots]$ but I also identify as genderqueer $[\ldots]$ because even though I feel more strongly as a male person, there is also the female part of me $[\ldots]$ a little bit of female and a lot of male.

...I identify as queer. And for me, queer means that I am not straight, but that the gender of the person does not matter that much. It is also a political statement.

...In Brazil, I am seen as white and when I look at myself in the mirror, I still see that. But, I am totally aware that [in the Canadian context] I am actually a 
person of colour [...] I am mixed-race. My father's family is from Eastern

Europe and my mother's family is more ethnically Brazilian.

...I identify as a "non-artist." I don't like that label [...] Sometimes people do

look down on you because you don't have the training and you didn't go to art

school [...] So I guess, being sarcastic and using black humour, that's why I say

I am not an artist.

By allowing Luka to identify himself ${ }^{8}$, I am trying to avoid collapsing Luka, the person, into identity labels that would most likely consume the reader's view of him. So often in positivist research the person is mechanically labeled as "male" or "female," and/or as "white" or "visible minority". I view this as an imposition of power by the researcher that collapses the person into a category. This is especially true when considering the inherent complexities of queer identity. Merely listing the socially constructed categories of gender, race or sexual orientation that describe Luka would be an oversimplification of his identity and would act to reinforce the normalcy of these constructed categories.

The positivist ideals of "objectivity" and "neutrality" are equally problematic as generalizability. As Code (1993) asserts, “...ideal objectivity is a generalization from the subjectivity of quite a small social group, albeit a group that has the power, security, and prestige to believe that it can generalize its experiences and normative ideals across the social order..." (22). In other words, "objectivity" and "neutrality" are myths of heteropatriarchy and colonialism. It is important to note that these myths are also sustained within communities on the margins of society by systems of homo-patriarchy, feminist colonialism, homo-patriarchal colonialism, post-colonial homophobia and sexism, and queer nationalism. Sandra Harding (1993) argues that "objectivity" and "neutrality" lead

\footnotetext{
${ }^{8} \mathrm{I}$ am using male pronouns rather than the gender-neutral pronouns that are used increasingly in queer scholarship. I asked Luka which pronouns I should use in my write-up and he told me he was most comfortable with male pronouns but noted that he liked the concept of gender-neutral pronouns.
} 
to a presentation of knowledge as, "the view from everywhere and nowhere" (42). Herein lies the power of "objective" knowledge building. Once knowledge is separated from the producer(s) of knowledge, "for empirical reasons and under empirical conditions", and once this same knowledge is "proven" to have a "mystical connection" to the historical progression of knowledge, it then becomes naturalized and incontestable, as any knower can be said to arrive at the same conclusions through "self-consciousness" (Marx and Engels 1976, 41). Thus, knowledge takes on an ideological character as the production of knowledge is effectively hidden from view (Marx and Engels 1976, 41). As Code (1993) argues, "...by virtue of detachment, these ideals erase the possibility of analyzing the interplay between emotion and reason and obscure the connections between knowledge and power" (16). I would like to further Code's (1993) argument by suggesting that, not only do the ideals of objectivity and neutrality erase the interplay between emotion and reason, but they also demarcate emotion from reason. Through the ideals of objectivity and neutrality, reason is positioned as the binary opposite of emotion. Constructing emotion and reason as mutually exclusive ignores the emotions of righteousness, dominion, and superiority in which patriarchal rationality, and by extension objectivity and neutrality, are rooted.

If the role of objectivity and neutrality is to render the researcher invisible, then (in the social sciences) it is also to render the subject or social group researched ultravisible. Neutrality acts to summon the voyeuristic gaze of the dominant groups and expose the research subject or social group to the judgment, criticism, and fault-finding that would otherwise be directed at the researcher. In this way, research subjects are positioned as objects of research (Oakley 1981). As Code (1993) explains, "The aim of 
[objective] knowledge seeking is to achieve the capacity to predict, manipulate, and control the behaviour of the objects known" (17).

While compiling my literature review I paid close attention to the methodologies of scholars whose research was closely related to mine. One book that I draw from quite frequently is Maite Escudero-Alías’s (2009) “Long Live The King: A Genealogy of Performative Genders". While this book does provide a valuable analysis of drag king performance, I found that some of the research methods used by Escudero-Alías (2009) ended up positioning the subjects of research as objects. In the "Acknowledgements" and "Introduction" to her (2009) book, Escudero-Alías writes,

The fact that most interpretations and analyses of drag kings' acts have been embodied by insiders within the drag king phenomenon may suggest certain lack of critical distance, and this is precisely what the present research intends to counteract (1).

Not coincidently, the book's most innovative ideas are based on my own location as an outsider to drag king culture. While certainly not a drag king, I am nevertheless an insider to non-heteronormative identities, familiarized with Other-ed ways of belonging and being... it is precisely this in-between positioning that has allowed me... to contest the so-called subversive nature of their on and off stage gender acts passionately (ix).

In positioning herself as objective, Escudero-Alías refuses to acknowledge the ways that her "critical distance" may actually be a position of privilege and power. She then spends a significant portion of the book critiquing the photographic representations of various drag-king performers, on how masculine they appear to be, The fact that Stafford [...] takes testosterone hormones does not make any difference in terms of making her body look more masculine. In fact, Jackie's 
torso $[\ldots]$ may even look more masculine than Stafford's, since there are other ways of building muscles apart from taking testosterone. However, the fact that Stafford takes testosterone makes her have a line of hair below her navel (77).

This descriptive analysis, in particular its focus on hormones and body-parts, which has little to do with how subversive or non-subversive the performance is, acts discursively as an "outsider" gaze that maps a set of presumptions based on a normative gender construct. This discursive mapping of Stafford and Jackie's bodies acts in the same way that the "male gaze" does in the aesthetics of film to "objectify" the female subject. As Laura Mulvey (1975) argues, “One part of a fragmented body destroys the Renaissance space, the illusion of depth demanded by the narrative, it gives flatness, the quality of a cut-out or icon rather than verisimilitude to the screen" (9). Mulvey $(1975,9)$ is referring specifically to camera close-ups of female body parts, "legs" or "face" for example, that act to fragment the female body and thus her person, positioning her as an object. Although Escudero-Alías's presents a photograph of Stafford and Jackie's whole bodies, the accompanying text acts as a camera, focusing the reader's gaze on specific heterogendered body parts, "torso" or "navel", discursively fragmenting their bodies and positioning them as objects ${ }^{9}$. The voices of the performers she writes about are remarkably absent from Escudero-Alías's (2009) work, which acts to further objectify them.

\subsection{Positionality}

In order to resist objectifying the subjects of their research, feminist, queer, and post-colonial scholars have called for the researcher to be written into the research. If all

\footnotetext{
${ }^{9}$ This is especially ironic when considering the following excerpt from a review by Sarah E. Cooper printed on the back cover of the book, "Objective without being objectifying..."
} 
scholarship is partial, incomplete, and socially located ${ }^{10}$, then it is necessary for researchers to disclose their stance and position (Lincoln 1995), paying particular attention to privilege and power. Scholars should devote as much thought to the attributes and peculiarities of their social location and the emotional and subjective ways of knowing that accompany it, as they do to the knowledge they are creating (Code 1993). This requires constant reflexivity throughout the research project. As Kerry Daly (1997) argues, "Positionality needs to be evident in all aspects of the social science text, including theory" (360). Dorothy Smith (1999) insists that reflexivity and positionality are also instrumental in encouraging the reader of knowledge to reflect upon their own social location. It is important for the writer of knowledge to guide the reader of knowledge through their reflexive practice constantly questioning the assumptions guiding their research so that the reader may also become aware of their own preestablished assumptions and open to ideas that might challenge these same assumptions.

This is where I am situated in the act of trying to understand, in the act of producing knowledge. Situating myself in relation to Luka, it is important to note a few things. Since I do not identify as trans or genderqueer, it is important for me to constantly question my assumptions about gender. I agree with Kate Bornstein (1994) that fixed gender categories work for no one, and I also agree with her assertion that we should be open about the ways that these categories do not work in order to undermine their influence on our collective imagination, but to go into details about my own gender negotiations would require a lot of introspective thought and could consume an entire paper on its own. I am aware; however, of ways in which my gender identity requires

\footnotetext{
${ }^{10}$ Recognizing that knowledge is always incomplete and partial also means recognizing, and remaining open to, the disorder and serendipity inherent in knowledge building, once more suggesting the possibility of an "anarchistic epistemology".
} 
Blues: The Madonna Show - A multimedia performance by queer women of colour, and Refugee Pride: Queer Deportations - a short film screening documenting the experiences of queer refugees in Toronto. It was through this process of participant-observation that I became acquainted with Luka. Of all the performances I observed, Luka's performances at Gender Play, Colour Me Drag, and Artwherk! stood out in their complex explorations of identity and their engagement in a community-level politics. I was also intrigued by a line in Luka's performer profile in the Gender Play playbill that read, "He enjoys storytelling $[\ldots]$ and rebelling when the word 'community' is misused" (Central Toronto Youth Services 2009). I was introduced to Luka at the Artwherk! event by a mutual friend who knew of my research interests. I shared these interests with him the time but did not ask him to participate. It was not until after Pride Week 2009 was over that I contacted Luka by email to ask him to participate in the research (See Appendix 1 for recruitment email).

The second major part of my research was a series of in-depth interviews with Luka, whose performances I had seen during Pride Week. Rejecting the "myth of objectivity" (Glick 1999), and avoiding the objectification of the research subject, I invited Luka to guide the research process. As much as possible, this involvement included discussions at a theoretical level. This served to avoid imposing theory on Luka and to generate theory statements from the ground-up (Daly, 1997). I conducted a series of four interviews with Luka, each spanning between one and three hours. These interviews were semi-structured in order to allow Luka to guide this "shared" research and provide his input of what he knew to be important factors in the shaping of "identity" and "community". Holding several, rather than one, interview with Luka allowed both of 
us time to think about the knowledge we were sharing and to come back with questions to guide or challenge each other's understandings. After each interview session I immediately transcribed the interviews so that I would be able to return with clarifying questions at the next interview session. The interview questions that I developed were open-ended, to encourage the sharing of narratives or stories (See Appendix 2 for interview shedule). During our first meeting, I provided Luka with a copy of the interview questions and prompts, as well as, an in-depth theoretical description and overview of the study in order to encourage his input, criticisms, and ideas (See Appendix 3 for the study overview). Luka's involvement extended into the analysis of his performances, and he was given a chance to read over my written analysis in order to provide suggestions, criticisms, and to ask certain things to be omitted or added ${ }^{13}$. We were also able to share theoretical interpretations of his work in order to determine the role of theory in both of our understandings of Luka's performance. Luka and I discussed confidentiality several times throughout the research process. As a public performer, he did not feel the need to mask his name with a pseudonym and felt that it was important to claim his story as his own. I would argue, as other scholars have, the confidentiality does not always suit the goals of feminist or queer epistemologies, particularly when the group represented is one whose stories are often rendered invisible by power relations (DeVault and Gross 2007).

Like Escudero-Alías (2009), I used photographic representations in my analysis of Luka's performance. I took these photographs in a dance studio at Ryerson University, where Luka ran through his performance for me. Luka's reenactment of his performance

\footnotetext{
${ }^{13}$ Luka and I reviewed all of the excerpts used in this work in order to ensure that they were used in the correct context and to ensure that they accurately reflected Luka's experiences, so that nothing would be included in this work that Luka did not wish to include.
} 
represents the third major part of the research. It is important to note that the power dynamics of Luka performing for me alone are different than they were when Luka performed at Pride Week for a larger audience. In my discussions with Luka I shared my fear that this form of representation might subject him to not only my voyeuristic gaze, but also those of the readers of this work. His response was to say,

Don't worry, I am comfortable with cameras [...] We are doing a Genderplay documentary, so I am used to it.

To avoid objectifying Luka and to resist voyeurism I allowed Luka to go through the photographs and choose, without my input, which ones we would use, if any. In analyzing the photographs, Luka and I sat down together and discussed different ways to analyze these photos and how they were representative of his performance as a whole. In coding the transcriptions of my interviews with Luka, I decided to focus on the themes that Luka had identified during these analytical discussions. These themes include: working with personal material in performance, having two "homes", the importance of in-between or liminal spaces, the politics of defining drag, and the intersections of queer and transnational identity. By including Luka's voice in the analysis, I am bringing him out of the realm of research object and positioning him as an active research subject.

\subsection{Conclusion and Discussion}

In this chapter I have presented the methodological framework for my research, as well as, the epistemological theories that guide this methodology. I have also introduced Luka, whose life experience is central to this work, and whose participation and contribution has enriched this work by grounding it in a dialogic process of knowledge building rather than mere subjective observation and reasoning. It is imperative when drawing on a queer theoretical framework, not to use a methodological approach that 
reinforces an essentialist and homogenizing discourse that, in turn acts to fix identity. It is also important that I do not recreate the same oppressive power structures I am arguing against within my research. I believe that the methodological framework presented in this chapter, with its focus on positionality, reflexivity, and dialogic process between researcher and research subject, is best suited to my epistemological goals.

\section{Literature Review}

\subsection{Introduction}

In examining the experiences of queer migrants, this work draws upon three broad areas of research: cultural citizenship, performative identity and subversive performance. The aim of this chapter is to critically review the existing literature on each of these three themes, identify gaps, and present the underlying theoretical framework to this work.

\subsection{Cultural Citizenship, Belonging and The "Two-Way Street"}

In examining the experiences of queer migrants as they move into and navigate through a "host" national or queer community, it is important to pay close attention to the notion of "citizenship" as it is linked to the broader analysis of "belonging". In other words, what can conceptions of "citizenship" suggest about the process(es) that queer migrants go through in achieving (or not achieving) a sense of "belonging" in the "host" national or queer community?

Traditional conceptions of "citizenship" have had a tendency to focus predominantly on civic, political and social rights (Shafir 1998; Stone et. al 2008), ignoring more abstract notions of citizenship as an interpersonal identity, or as a sense of belonging to a particular group or society. This conceptual gap is representative of what Harald Bauder (2008) terms "formal citizenship" (i.e. legal and institutional) and 
"informal citizenship" (i.e. practiced and cultural). According to Bauder (2008), informal citizenship is, "a dimension of membership in a national community related to practices of identity and belonging", as opposed to formal citizenship, which is, "a legal category that is strategically created, endorsed, and valorized by the collective membership of a national community and by the political elites who claim to represent them" (320). Both Frolic (2001) and Bauder (2008) note that, issues of informal citizenship and belonging are closely linked to Anderson's (1983) conception of the "imagined community", and the myth of a national identity. Those whose identities fit with the imagined national identity are constructed as "acceptable" citizens, while those who do not fit this identity are often invisible or constructed as non-citizens, not belonging. Several scholars have insisted that in operating this way, the notion of citizenship, whether formal or informal, is an exclusionary one (Poore 1996; Ong 1999; Rosaldo 1999), used to recreate and perpetuate existing class divisions within society (Bauder 2008). Other scholars, have focused on "integration", claiming that this process is a "two-way street" where both migrants and "host" communities have some degree of responsibility in ensuring that the former achieves or is granted informal citizenship in the later (Biles et. al 2008; Frideres 2008; Stone et. al 2008). I am critical of the "two-way street" integrationist approach as I feel it constructs an overly-simplistic binary between "migrants" and the "host community", ignoring situations where these categories can overlap (Bauder 2008). The "two-way street" approach offers a singular path to integration; though two-directional, there is only one street. I would argue that integration necessarily takes different paths for queer migrants who occupy different gendered, racialized, sexualized and other class based subject-positions. 
Nira Yuval-Davis $(1997 ; 1999)$ has argued in her work on the "multi-layered citizen" that citizenship and belonging are not uniquely attached to the nation-state, rather individuals are simultaneously citizens and members of multiple political communities ranging from neighbourhood organizations to international governance. For queer migrants, integration into the host country or society takes place not only at the national level, but also within the local queer community. Both Wray (2000) and Frolic (2001) propose that the queer community, similar to the nation, can be understood as an "imagined community", with its own conceptions of citizenship and belonging. Alan Sinfield $(2000,103)$ argues that for queer diaspora, "home" represents a destination rather than an origin, "Instead of dispersing, we assemble". However, queer scholars have become increasingly critical of the "linear narrative of [queer migrants] moving into a queer home/subculture" (Fortier 2001; Kuntsman 2007), as well as, the notion of moving from "repression" to "liberation" that is concomitant with this narrative (Manalansan 2003, 13; Luibhéid 2008, 170). In her critique of Sinfield's (2000) work on queer homecoming, Anne-Marie Fortier (2001) draws on Gilroy to state that narratives that construct migrants as moving on an undeviating or "straight" path into the queer community, present a "simple and unambiguous exile" (Gilroy 2000, 124 in Fortier 2001, 410). She argues that Sinfeild's (2000) work is, "reminiscent of the prototypical immigration narrative", where migrants are constructed as moving in a linear trajectory from one community to another (Fortier 2001,211). This narrative constructs the destination "community" as neatly bounded and spatially isolated from the migrant's community of origin (Fortier 2001,211). In the case of queer migrants it presents the "queer" community as discretely bounded, presumably homogenous and isolated from 
heteropatriarchal society (Fortier 2001, 211). Fortier (2001), has also observed that Sinfield's (2000) reversal of the traditional immigration narrative is no better than its original, as it romanticizes community, naively erasing or ignoring oppressive structures, such as patriarchy, racism, and class divisions that are widespread in the queer community, and fails to question or subvert these underlying power relations. I would add that any linear narrative of integration also necessarily constructs a journey or movement that is "straight".

In attempting to conceptualize the experiences of queer migrants in the queer "imagined" community, a more comprehensive examination into how migrants acquire a sense of "informal citizenship" is warranted. Numerous scholars have applied theories of "cultural citizenship" to demonstrate how aspects of informal citizenship, including a sense of belonging, can be realized (Ong 1993; 1999; Rosaldo 1994; 1999; Kymlicka 1995; Inda and Aguirre 1998; Wray 2000; Mercer 2002; Miller 2002; Andrew et. al 2005; Foote and Smith 2005; Stone et. al 2008). Delanty (2002) observes, via Williams (1976), that the word "culture" is one of the most "complicated words in the English language, possessing over 164 definitions. Thus theories of cultural citizenship are applied to a diverse amount of subject matter, varying greatly across academic disciplines and national discourses (Stone et. al 2008). To avoid confusion, unnecessary complications, and in order to operationalize "cultural citizenship", I will focus on the debate surrounding this concept in the work of Ong and Rosaldo. These scholars write from the "cultural sociology" discipline, which according to Delanty (2002), presents a 
more "far-reaching" conception of cultural citizenship than the political theory discipline, and which emphasizes the "centrality" of culture to the comprehension of citizenship ${ }^{14}$.

Rosaldo (1999) describes cultural citizenship as "the way that claims to citizenship are reinforced or subverted by cultural assumptions and practices". In his examination of the Chicano/a movement in the United States, he extends several examples to demonstrate how cultural citizenship operates (Rosaldo 1999). On one hand, he states that popular representations of the US/Mexico border, particularly on the nightly-news, construct Latina/o migrants as a violent threat to the national body, which in effect subverts Latina/o claims to citizenship (1999). On the other hand, he asserts that the same Latina/o groups can use "cultural expression", for example positioning a statue representing an Aztec divinity in American urban space, to claim public rights and representation (1999).

Ong (1999) presents cultural citizenship as a process of "subject-ification", or the making of "cultural citizens" in "the Foucaldian sense of self-making and being-made by power relations...”. Ong (1999) argues that Rosaldo's (1994 and 1999) conception of cultural citizenship "attends to only one side of a set of unequal relationships", mainly the side of those "claiming" citizenship, and therefore, "gives the erroneous impression that cultural citizenship can be unilaterally constructed and that minority groups can escape the cultural inscription of state power and other forms of regulation that define the different modalities of belonging". Ong (1999) presents cultural citizenship as a series of uneven negotiations with, "the state and its hegemonic forms" that create and police the boundaries of the "imagined" national community. She states that, "Cultural citizenship

\footnotetext{
${ }^{14}$ I am also choosing to focus on these two scholars as they both draw on queer theory (via Foucault).
} 
is a dual process of self-making and being-made within webs of power linked to the nation-state and civil society” (1999). Ong's (1993 and 1999) understanding of cultural citizenship as "subject-ification" provides a more in-depth analysis of the ways migrants come to gain a sense of belonging to a national or queer "host" community. Turning to Butler's (2004) discussion of the Hegelian desire for recognition, which will be discussed in greater detail in the following sub-section, shows that, in seeking recognition we cannot "remake the world", and that, in falsely imagining ourselves to posses this "godlike power" we are denying, "the ways we are constituted, invariably and from the start, by what is before us and outside us". Thus, conceptions of integration that position queer migrants as happily fitting into a "host" queer community, or that argue for the "two-way street" approach to integration, ignore the complex webs of power and interlocking sites of oppression that position queer migrants as outsiders to the queer community and broader society from the very beginning.

\subsection{Performantive Identity, Performative Community}

As mentioned in the previous section, the notions of "cultural citizenship" and "belonging" are inextricably linked with the notion of identity. In their analysis of cultural citizenship, Stone et. al (2008), quote Benhabib (2002) in her discussion of "culture" to make the point that, "Culture has become a ubiquitous synonym for identity, an identity marker and differentiator...”. Several scholars of citizenship and cultural citizenship have noted the strong connection that these concepts hold with the notion of identity (Ong 1993 and 1999; Rosaldo 1994 and 1999; Kymlicka 1995; Inda and Aguirre 1998; Mercer 2002; Bauder 2008). In particular, scholars have noted how the identity of migrants affects their positioning in relation to hegemonic forms of state power, which in 
turn affects their negotiations of belonging (Ong 1999; Bauder 2008). Identity politics, like cultural citizenship, is a vast area of inquiry, thus I am choosing to focus on poststructuralist and queer theory critiques of identity, mainly performative identity theory.

Performative identity theory is heavily derived from the theories of Foucault. Accordingly, it is important to understand Foucault's basic conception of "identity". Foucault (1977) argues that, "the body is the inscribed surface of events". In other words, identity can be understood as an inscription on the body (Foucault 1977). Moreover, history, which he defines as the creation of values and meanings through signification, acts to weaken the body through power relations, surveillance and disciplinary measures, that dominate and discursively "destroy" the body (Foucault 1977). Butler (1990) is critical of Foucault's stance and argues that the theory of identity as "inscription" falsely assumes a presupposed "body", one that exists prior to cultural inscription (165-166). Butler (1990) argues that there is, in fact, no pre-determined body (165-166). Rather, the body itself and the identities that accompany it, such as gender or sexual orientation, are brought into conscious understanding through reiterative acts and discourse (Butler 1990, 126-141). For Butler (1990), these identities are structured through the repetition and recitation of public and shared actions. Butler (1990) argues, "that the gendered body is performative suggests that it has no ontological status apart from the various acts which constitute its reality" (136).

Jonathan Inda (2000), draws on Butler's theory to argue that, "race resolutely does not refer to a pre-constituted body" (75). Inda (2000) continues by adding that "race" may have a foundation in biology, but, "it is really just a name, albeit a very powerful one, that retroactively constitutes and naturalizes the groupings to which it refers" (75). 
This is not to suggest that discursive constructions of race happen in exactly the same way as constructions of gender or sexuality. Gender constructs shape identifiable bodies into two camps, ignoring, denaturalizing and pathologizing biological occurrences of intersexed, transgendered, or transexual bodies, and by prescribing physical and behavioural cues to "male" and "female" bodies that socially limit their actions and desires (Bornstein 1994, 30-31). Constructions of sexuality are inextricably intertwined with constructions of gender in that the constructed boundaries of the male and female body limit that body's options for sexual activity (Bornstein 1994, 38-40). In constructing racialized bodies, borders are drawn through the biological continuum of skin colour to create identifiable "skin colours", and phenotypical characteristics, such as nose or eye shape, that are assigned to, and identified with, these various colours (Inda 2000). These identities, which shape culturally recognizable bodies, are also interlocking as every subject is at once gendered, raced, classed, sexualized, able-bodied or disabled, and more (Muñoz 1999, 8).

After Butler's (1990) book, Gender Trouble, a proliferation of essays were published celebrating performances of parody, drag in particular, as the voluntarist and subversive self-construction of identity (Sullivan 2003, 88-90). In examining identity as performative, one should be careful not to fall into the "voluntarist trap" (Sullivan 2003, 88-90). The scholars taking a voluntarist approach argued that identity is a choice that can be worn like clothing (Sullivan 2003, 88). In her response to this (mis)interpretation of her work, Butler (2004) argues that what these scholars ignore are, "the ways we are constituted, invariably and from the start, by what is before us and outside us" (3). Butler (2004) argues that the voluntarist approach to identity mistakenly assumes that through 
"consciousness" we can achieve the "godlike" power to erase history and eradicate identity boundaries. Further, that identities are "interlocking" indicates that the borders to identity are not easily disentangled from one-another through voluntary action (Muñoz 1999, 8). This too complicates attempts to self-construct identity. Butler (2004) goes on to discuss the Hegelian desire for recognition, where she argues that identity constructs are powerful because of the human desire for recognition and a sense of community that reaffirms identity (2-9). In situations where one's identity is not recognizable or positively reinforced in any community, life becomes "unlivable" and identity is lost (Butler 2004, 3). Butler (2004) concludes that it is therefore impossible to "remake the world" and eliminate the boundaries of identity (2-9). We should instead resignify and contest these boundaries so that they come to be understood as. fluid, porous, and fractured (Butler 2004, 2-9).

Queer theorists have asserted that, while identity constructs have been subject to post-structuralist critiques of subjectivity, the notion of "community" as a compilation of individual group-members with a shared identity, has "remained strangely immune to these debates" (Secomb 1997; Sullivan 2003). Linnell Secomb (1997) argues that the underlying assumption in most uses of "community" is that subjectivity or identity is fixed, singular, and mutually exclusive. However, as structuralist theorist Mary Douglas (1966) argues, "the body is a model that can stand for any bounded system. Its boundaries can represent any boundaries which are threatened or precarious..." Drawing on Douglas's (1966) conception of the body, we can expand the use of Butler's theory to the "imagined" collective identity of community. If the boundaries of the body are discursively constructed, so too are the boundaries of community. Systems of 
representation, repeated cultural images, visual speech and narratives, provide a standard model of comparison that discursively bounds a singular community in relation to other, outside communities (Hall 1994, 276-278). Therefore, attempts to define community end up shaping and bounding community by excluding members or elements of identity that seem to contradict the desired homogeneity of the shared narratives and images that represent it (Young 1986, 3).

It is important to mention that it is in "communities", whether national, or local, or even queer, where the discourses that shape identifiable bodies take place. Sullivan (2003) argues that, "subjectivity is constituted in and through relations with others and thus is never autonomous, singular, unified, or static, but rather, is relational, heterogeneous, fractured and in-process" (146). Thus, identity is shaped through interactions with community and in the discursive bounding of community, the discursive bounding of the body also occurs. As Shane Phelan (1994) argues, "identity does not preexist community" (81). Allan Bérubé $(2007,363)$ calls these the imagined community identities the racialized, gendered, sexualižed, and otherwise classed, "phantom figures that hover over... [us] and inhabit our consciousness". He argues that for the gay community, this phantom is a white, upper-class male (Bérubé 2007,363). This is significant for queer migrants, especially those that do not occupy white, upper-class or male subject-positions, as it is their identities that constitute a threat to the imagined and desired totality of "community".

Thus, the relationship between identity and community can be understood as cyclical. Communities provide the space for identity shaping discourse and this discourse necessarily binds identity in identity's desire for recognition. Through uneven access to 
sites of recognition upper-class, white, gay male bodies are made most visible and privileged. This visibility constructs the community itself as "upper-class", "white", and "male". Because communities are sites for the reaffirmation or strengthening of precarious subjectivities (Pendleton Jiménez 2005; Ellis 2007; Leap 2007; Hammers 2008), the lack of visibility for racialized and/or transnational queer identities leaves these identities vulnerable to assimilation and relegates queer migrants and racialized queer identities to the margins of queer communities. Some queer scholars have argued that this positions queer identities and racialized or transnational identities as mutually exclusive, making membership in queer communities contingent upon the denial or suppression of racialized or transnational identities (Young 1986; Silvera 1990; Chang Hall 1993; Manalansan 1997; Sullivan 2003; Pendleton Jiménez 2005; Kuntsman 2007). In this way, community is fractured, and queer communities gain a reinforced "whiteness" in the constructed incompatibility of queer identities and racialized or transnational identities.

What is underlying all of these discussions of constructing identity through a lens of whiteness is the idea that gay and lesbian communities do not exist within a vacuum, free from the oppressive power structures and relationships of broader society. Several scholars have noted the effects of heteropatriarchy in rendering lesbians and lesbian communities and businesses "invisible" both within the queer community and mainstream society (Wolf 1980; Valentine 1989; Adler and Brenner 1997; Podmore 2001). Others have noted the capitalist underpinnings and classist implications of the valorization of the "gay dollar" and the commodification of queer life, which have led to the exclusion of low-income queer people (Sears 2005, 105). 
Similarly, queer migrant scholars have noted the effects of ethno-centerism in queer communities. Martin Manalansan (1997) argues that the universalized acceptance of Stonewall ${ }^{15}$ as the modern day catalyst for the global queer rights movements has imposed a Eurocentric politics on queer migrants ignoring significant moments in other parts of the world and valorizing "outness" and "coming out" as the ultimate political acts, while ignoring the fact that "outness" is a privileged position. This valorization of "outness" is often tied to "neo-liberal constructions of the sovereign, individual, selfrealized gay subject" that leave racialized queer communities and queer migrants stereotypically associated with backwardness or internalized homophobia (Decena 2008). Several scholars have argued that queer activism, centered around coming or being "out", is often inappropriate, dangerous, or isolating for queers migrants, as well as racialized queers who are placed in the vulnerable position of loosing ties with their family or ethno-racial community through this “outness”(Silvera 1990; Mercer 1994; Manalansan 1997). In loosing their places in their families or racialized communities, racialized queers risk loosing one of their only shelters from the racist oppressions of broader society, as well as, an important part of their own identity (Silvera 1990). It could conceivably be argued that the same increased risks apply to anyone who is doublyminoritized including lesbians who risk loosing access to women's spaces, as well as, lesbian mothers who risk loosing their children in coming. However, because race and ethnicity are most often inherited genealogically, the family can (though not always) provide a unique shelter from the racial oppressions of the outside world. Gender

\footnotetext{
${ }^{15}$ The Stonewall riots were a series of spontaneous and sometimes violent demonstrations against the police that took place on June $28^{\text {th }} 1969$ at the Stonewall Inn in New York City's Greenwich Village. They are often cited as the first time that gays, lesbians, and transgendered people fought back against government-sponsored persecution of homosexuals, mainly police raids of gay bars.
} 
oppression is much more likely to be recreated within the heterosexual framework of the family and thus the analogy of the white lesbian coming-out experience being similar to that of any racialized queer person does not hold up. This is not to suggest that white queer people value or need family any less than racialized queer people, rather that family does not constitute exactly the same type of shelter from some forms of outside oppression. Pointing out the problematic aspects of valorizing "outness" is also not meant to comparatively measure the status of different queer subjectivities, but rather to expose identities as interlocking and embedded at different points in webs of power, including the heteronormative structure of the family, that differently affect how a persons multiples subjectivities relate to and interact with one another.

Communities can be reluctant to challenge the internal manifestations of broader oppressive systems because of a focus on a single aspect of identity. In her discussion of Jamaican Canadian lesbian identity, Makeda Silvera (1990) argues that the black community in Canada has been slow to question its own homophobia because of fears of loosing what few privileges they already have and further "othering" an already vulnerable group. Bérubé (2007) seems to express a similar anxiety in his multiple discussions about his fear of alienating himself from the queer community in his work on anti-racism. Though they may seem like similar fears, there are some differences that should not be overlooked or negated. While gay and lesbian identities do have a history of being violently policed, controlled, and put under surveillance by state institutions, the racism in white gay and lesbian communities is derived from the unquestioned privileges of whiteness that white gay and lesbians experienced in growing up white; it comes from a position of power. The homophobia of the many racialized communities however, is the 
exasperated result of colonialist oppression that positioned the colonized community as "effeminate" (Young 1996; Mercer 1996). Thus the hyper-homophobia expressed by some racialized groups or migrant communities is in response to colonialism, an attempt to challenge colonialism by becoming the extreme opposite of the colonized subject (Young 1996; Mercer 1996). It does not come from a position of power, but from a position of desperate opposition. This is not to excuse either the racism of gay and lesbian communities or the homophobia of racialized communities, but simply to question where these oppressive structures may come from so that race does not get collapsed into sexuality.

In her analysis of the use of "power" in the feminist movement, bell hooks (2000), argues that there is a fundamental difference between power that is a source of domination and control, and power that is creative and "life-affirming". She states that, in positioning themselves as "powerless victims", mainstream feminists have often argued for the accrual of power within the existing social structures without questioning how these structures are oppressive to women of colour (hooks 2000). In failing to examine their own racist, classist, or patriarchal structures and attitudes, mainstream queer communities have expressed a fear of loosing privilege and further "othering" a vulnerable group. However, by maintaining privilege, queer communities are failing to revolutionize existing power structures and are actively participating the oppression of queer migrants and racialized queers. Essentialist discourses, such as those embedded in "Queer Nation," ignore existing oppressions within and between queer communities, and function in a domineering way to accrue power for the queer mainstream without destabilizing oppressive structures such as patriarchy and white supremacy that 
contribute to upholding the heterosexual matrix. In terms of integration, this means that queer migrants are often faced with difficult questions of identity while trying to integrate into a community that actively constructs them as outsiders and the community boundaries as innate and immutable. Like hooks (2000), I argue that collective and lifeaffirming uses of power, those that do not perpetuate existing hegemonic social structures, can be used to create connections yet resist essentialization and oppression in the queer community.

\subsection{Subversive Performance, Subversive Bodies}

Performances that are based on or that explore identity and the politics of identity could provide unique sites for the "creative" and "life-affirming" uses of power that hooks (2000) describes. As Bornstein (1994) argues, performance that is centered around "self-discovery" and "transformation" is powerful in its ability to engage the audience and to bring them "along for the ride" (161-162). In doing so, these performances affect personal transformation in audience members, even if that transformation is brief, coming in the form of the simple but complex question, "who am I?" (Bornstein 1994, 161-162). Several scholars have argued that queer artists, particularly racialized and/or migrant queer artists, have been at the forefront of working both with and through post-colonial and queer theory to challenge fixed identity constructs, community and national borders (Anzaldúa 1987; Mercer 1996; Walcott 2006). This subsection will explore various types of performance, mainly identity-based performance art, such as drag, in its ability to creatively reveal, destabilize, and resignify the boundaries of community and identity. There will also be some discussion of other forms of identity-based performance art, including short film, strip-tease, and ethnic spectacles. 
In discussing performances as "subversive", many scholars fail to qualify exactly what it means to be subversive. Often subversion is written in a way that suggests that it is quantifiable. A performance can be more or less subversive than other performances, but exactly what is being measured is never laid-out in great detail. The term itself is rather elusive of an operational definition. In queer theory, it is used generally to refer to a performance that in some way challenges or undermines socially constructed truths such as "there are only two genders", nationalist myths such as heterosexual "family values", or dichotomies that position some identities in hierarchy over others such as white supremacy. However, because the political usefulness of a performance is so dependant on the power structures it is embedded in, the performer's intentions, how the audience reads the performance, among other things (Sullivan 2003), it is difficult to define a generalizable definition of subversion. Thus, I do not find it useful to talk about subversion in an absolute or quantifiable way and resist the labelling of performances as more or less subversive than one another. Rather, it is more useful to discuss how a performance may have subversive elements in a particular context, while acknowledging that the same performance may have problematic elements that reify the very structures it is at the same time subverting. I do not think that subversion necessarily occupies an either/or category. A performance is not simply subversive or non-subversive, it may in fact have elements that are both. It is also important to acknowledge that there is more than one way for a performance to be subversive. Thus, in the following subsection, as well as in the fourth chapter of this work, when I speak of a performance as being subversive, I will try to contextualize and point to specific elements of that performance that are subversive. Similarly, if I point out problematic elements of performances that 
other scholars have labeled as subversive, it is only to open up those performances to critical discussion and not to deny their other possibly subversive elements.

In discussing identity as it is attached to the body, the performance of some identities can act to destabilize identity constructs by suggesting a porosity or fluidity to the boundaries of the body. For example, Butler (1990) draws on Simon Watney (1988) to argue that the homosexual (male) body is threatening to heteronormative identity constructs in its performance of anal sex, an act which suggests a porosity to the body by its literal penetration of constructed bodily boundaries (168). Several scholars have focused on the subversive elements of drag performance in destabilizing fixed gender identities and challenging the construct of the gendered body by demonstrating its fluidity (Butler 1990; 2004; Halberstram 1998; Volcano and Halberstram 1999; Sullivan 2003; Walcott 2006; Escudero-Alías 2009). In discussing drag kings and female masculinities, Judith Halberstram (1998) argues that, "Far from being an imitation of maleness, female masculinity actually affords us a glimpse of how masculinity is framed as masculinity" (1). Other scholars have vilified drag kings in particular and especially FTM transgender ${ }^{16}$ drag kings as the ultimate "betrayal" of feminism in their identification with patriarchal masculinity (Case 2009, 10-12 and 24-29). Sue-Ellen Case (2009) argues that while the performances of MTF transgender drag queens are subversive in their deconstruction of masculinity, the performances of FTM drag kings act only as "an amplification of men's" roles (10). I would argue that Case's argument wrongly collapses all forms of masculinity

\footnotetext{
${ }^{16}$ I find Case's (2009) critique to be especially problematic as it is aimed at a particularly marginalized and vulnerable group that does not benefit from the same human rights protections that gay men and lesbians often receive, and who continue to suffer the persecution of having their identity classified as a mental illness in the Diagnostic and Statistical Manual of Mental Disorders, something homosexuality was removed from in 1973. It also ignores the fact that many trans-men, including Luka, identify as feminists.
} 
into violence, "An interest in the masculine still smells of Agent Orange"17 (Case 2009, 29). As Gloria Anzaldúa (1987) writes, "Lumping the males who deviate from the general norm with the man, the oppressor, is a gross injustice" (106). Case's (2009) argument also perpetuates patriarchal structures by continuing to privilege those assigned a male body at birth. Case (2009) ignores the profound subversion of power relations that occurs when anyone who has been assigned a woman's body, takes ownership of their body, whether it is to express their gender identity or their sexuality or for any other reason, in a time and place where women's bodies and sexualities are still vilified, policed, and controlled.

Butler (2004) argues that while drag can act subversively, it would be naïve to read it as existing outside of the confines of gender, or as a means to totally eradicate gender constructs. She points out that the body in drag is always a body betrayed by gendered constructions, and that drag's subversive elements are precisely these betrayals as they act to make visible the boundaries of gender (Butler 2004). Rinaldo Walcott (2006) analyzed the performances of a group of black drag queens in Toronto, as they were presented in the documentary Divas: Love Me Forever (2001). Walcott (2006) expresses the subversive elements of drag in his discussion of the performances of Duchess and Michelle Ross who often remove their wigs near the end of their performances to reveal masculine haircuts. Walcott (2006) argues that this acts to "deconstruct" their

\footnotetext{
${ }^{17}$ Case (2009) argues that her own identity, a "butch hippie" is "more subversive" in its identification with the feminine, as embodied by long hair, flowery shirts and a politics of passivity, She writes, "We were seeking to be 'gentlemen,' in the best sense of the word, if we understood butch to have any referent among men... You know, there was that Brit fashion of puffy sleeves - the courtier style" (24). However, in contemplating intersections of race and queer sexuality, I would argue that this performance "still smells of" colonialism, as these British courtiers historically served the same monarch that wrecked havoc, decimated natural resources, and committed genocide against the indigenous populations of British colonies.
} 
performances and signify the performers as "men in frocks", destabilizing not only the gendered "illusion being performed, but all the various gendered categories we might imagine" (128). Escudero-Alías $(2009,158-159)$ also refers to the "deconstruction" of drag performance in her discussion of MilDred, a popular New York drag king featured in the documentary Venus Boyz (2001). While MilDred does play with both male and female, heterosexual and homosexual, gender identities, the final scene of her performance, a "provocative striptease removing some of the markers of masculinity", set to Arethra Franklin's, "Woman", acts to "deconstruct" her performance, "through a process of identity self-construction" (Escudero-Alías 2009, 158). Escudero-Alías (2009) argues that this "deconstructed" performance is subversive, while the performances of butch or FTM transgendered drag kings ${ }^{18}$, “who want to 'look' as real as possible” are not (158). She goes on to say that the audience will always read MilDred's striptease as "identity self-construction" while "fully-committed to acknowledging that all gender categories are performative events" (Escudero-Alías 2009, 158). Yet it is unclear how the audience would automatically reach a conclusion that gender is a performative category. While MilDred's drag performance has the ability to subvert constructed gender categories in it's acknowledged performance, MilDred's striptease, in its exposure of the "natural woman" beneath the various drag identities she performs, does more to reinforce the bounding of recognizably gendered bodies. I would argue that these scholars' focus on the "deconstruction" of the gendered performance, in both of the examples discussed,

\footnotetext{
${ }^{18}$ Escudero-Alías (2009) argues that drag kings generally fall into three categories: femme lesbians, butch lesbians, and FTM transgendered drag kings. She furthers this statement by saying that femme lesbian drag tends to be "more subversive" in its ability to "genderfuck", while butch lesbian and FTM transgender drag tends to valorize "passing" (58-129). This is a gross generalization that erases the agency of drag kings by writing their behaviour as predetermined based on their social locations. Like Case's (2009) discussion, it too ignores the subversion that happens when anyone who has been assigned a female body at birth takes ownership of their body, radically altering it, in order to express their inner-selves or desires.
} 
still points to a "natural" gendered body underneath the costume of performance, and in doing so presents a conception of gender that still relies on the socially constructed gender binary.

Performing mixed race identities can act to destabilize the borders to racial bodies; however the borders are re-stabilized when mixed races are conceptualized as moving closer to, or farther away from, bounded "whiteness" through the generations. Racial constructions hold a different power, in that they are highly difficult to resignify racial categories or demonstrate a fluidity to race, as it is so inextricably tied up to naturalized phenotypical identity markers. This does not mean that it is impossible. In discussing the performance of Toronto performer Chris Edwards as Dolly Parton, Walcott (2006) writes that,

Encapsulated in this performance of white face is the obvious citation of the long and painful history of minstrelsy and its blackface foundation, but equally important is the contemporary insight of making whiteness a racial category, visible and marked (127).

Walcott (2006) argues that, in this performance, is the chance to rethink history, knowledge, and pleasure (127). This performance challenges constructed bodily boundaries by signifying the usually invisible category of whiteness as a visible, and therefore performative, identity. The white face drag of Chris Edwards is subversive, not because it eradicates racial constructs, but because it acts to make visible its boundaries; the white Dolly Parton is always betrayed by her black hands ${ }^{19}$.

If the performance of identities that do not fit the normative bodily mould can act to destabilize normative identities, then these same performances can act to contest the

\footnotetext{
${ }^{19}$ In Edwards' choice not to wear gloves, we can see the same conscious choice to "deconstruct" her performance as we do in Duchess' and Michelle Ross' choices to remove their wigs.
} 
boundaries of the "imagined community" and claim space. Similarly any act of claiming space also acts to contest identity constructs. We can, through performance, come to understand boundaries as fluid, constantly in negotiation, and open to resignification. For example, if we understand, the nation as a community, then it is within this community that bodies are constructed as citizens or non-citizens. Here, the citizen-body is shaped as white, heterosexual, and Canadian-born (Bannerji 2000; Razack 2002). If we understand the nation as body, then performances of transnational identity, from dancing at Caribanna, to sending home remittances, are destabilizing to national boundaries by suggesting that national boundaries do not entirely shape identity and by suggesting that the body can belong to more than one "nation" at a time. In discussing the role of "ethnic spectacles", such as Winnipeg's Folklorama, Paul Bramadat (2001) argues that the "dramatic" and "entertaining" performances that are often presented during ethnic spectacles are important in providing the space for the dialogue and negotiation instrumental in shaping and maintaining ethnic identities that are vulnerable to assimilation. Bramadat's argument is in contention to scholars such as Neil Bissoondath (1994) who argue that these same spectacles present culture as an, “object for display rather than the heart and soul of the individuals formed by it" (8). Bramadat (2001) counters Bissoondath's (1994) claims by stating that the objectification of culture is more a result of late capitalism than the functioning of ethnic spectacles in general (13). He contends that many ethnic spectacles, which are planned, directed, and written by members of the ethnic communities being displayed, act to provide an arena of selfrepresentation where communities have the opportunity to engage in the discursive negotiation of their own identities (Bramadat 2001, 5-7). Although these spectacles are 
embedded in the power structures and hierarchies of broader society, by "seizing control of the arena of cultural representation", ethnic communities may be able to exercise considerably more power in identity shaping dialogues than they would in other social domains (Bramadat 2001, 8). In shaping transnational identities, these spectacles act to mark "Canadian" space as transnational space, simultaneously challenging the meaning of national and community borders (Bramadat 2001).

Similarly, the performers discussed by Walcott (2006) are objectified and exoticized by a mainstream queer audience, while at the same time exercising considerable power in representing themselves on stage. Using strategies such as simulating sex with audience members and always finding that audience member to be "inadequate", allow the performers to uphold their power as representatives of self (Walcott 2006, 128). Walcott (2006) argues, these performances are subversive to the fixed borders of community not because they erase its borders, but because they, "point immediately to community as political designation, as political problem, as something that must be worked, and as something more" (126).

In the "whiteness" of gay and lesbian community space, the performances of queers of colour can be understood as contesting the boundaries of the queer community as a body. These performances act to critique the white gay community and the new "queer" visibility that is popularly associated with the white, male body (Walcott 2006). In her reading of the films of Cheryl Dunye, Linda Goldstein (1997) argues that in the 1990s, "Dunyementaries" ${ }^{20}$ were instrumental in claiming space for lesbians of colour at queer film festivals across the United States that until then had been dominated by the

\footnotetext{
${ }^{20}$ See Dunye, Cheryl (2008). The Early Works of Cheryl Dunye. DVD. First Run Features.
} 
works of white, middle-class gay men and lesbians. By using hand-held cameras, a very low budget, her friends as actors, and her own personal stories as subject matter, Dunye was able to interrupt the "white" queer film festivals of the 1990s (Goldstein 1997). It was not simply the presence of her films that acted to contest the white boundaries of the gay and lesbian community (Goldstein 1997). All of Dunye's films dealt with relationships between black women and white women as a microcosm for race relations in the broader lesbian community (Goldstein 1997). In doing so, Dunye's films pushed the white lesbian community to question not only its privilege but also its appropriation and fetishization of race (Goldstein 1997). The films were a bold statement of "claiming space" for racialized queer identities but left no room for the white lesbian community to congratulate itself on "welcoming" a woman of colour. Rather, the films forced the white lesbian community to question how its acts of "welcoming" may actually be grounded in patriarchal and colonialist appropriation of race and fetishization of racialized women (Goldstein 1997).

While the performances discussed above can be conceptualized as contesting the racialized boundaries to the gay and lesbian communities by "claiming space" for racialized queer identities, and, it should also be noted that some performances, intended to subvert boundaries, can actually act to reinforce existing boundaries, when the performers do not consider the historical significance behind their performance and the political space in which it is performed (Lloyd 1999). In their (mis)interpretation of space claiming performances, Bell et. al (1994) wrote an analysis of the gay male skinhead that celebrated the conscious and political appropriation of identity in order to subversively produce gay space within hyper-masculine and overtly heterosexual space. It is 
particularly troubling, in this discussion of interlocking racial and sexual identities, that Bell et. al (1994) did not consider that the image of the "skinhead" not only symbolizes a disgust for divergent sexualities, but also the ultra-violent oppression of people of colour. Moya Lloyd (1999) argues that Bell et. al's gay male skinhead image is not subversive, but rather oppressive in its significance to racialized gay men.

In his critical discussion of the ways that black queer artists have challenged Fanon's (1967) representation of black homosexuality in Black Skin, White Masks, Mercer (1996) writes that,
Salman Rushdie once talked about the many rooms of literature and Edward Said has invoked the many rooms in the house of culture; I would add that the closet is one of the most crowded rooms in the house of black diaspora culture. There must be a riot going on in there! (128).

If we understand "the closet" as not just a room to hide queerness in, if we also understand it as "the straightness of gayness" that Wark $(1997,6)$ speaks of, or as any process of othering that fixes certain identities to the margins of any cultural "house", then the "closet" of racialized queers and queer migrant's is also a closet in the house of queer culture. This metaphor offers some important clues in understanding how cultural performances can act subversively to negotiate belonging. Performances that focus on the intersections of racialized, ethnic, or transnational identities and queer identities can be understood as precisely the "riots" to which Mercer (1996) refers. Mercer (1996) is alluding to the idea that the "closet" is not just a self-made box that can be torn down with an act of "consciousness", by "talking the cure", by "coming out", or by "performing". This also hints at the Foucauldian "subject-ification" found in both Ong's (1999) conception of "cultural citizenship" and Butler's (1990) conception of 
"performative identity". Mercer's (1992) "riot" indicates that it is not just by “coming out" that racialized queers and queer migrants can escape the confines of the closet, this too would attend to only one side of an unequal set of power relations. Rather one must seek to understand how the "riots" in the closets of queer communities are acting to change the shape of the closet, punching holes in its walls, making these walls more malleable, tearing down sections and rebuilding others. By challenging the boundaries of community belonging, these "riots" also challenge the notion of belonging itself, exposing traditional integration narratives as fundamentally assimilatory, and act to assert queer migrants' desires to belong on their own terms.

\subsection{Conclusion}

Out of this review of the literature the conceptual framework for my research has emerged. Rather than understanding queer migrants as "integrating" into a "host" community, or as a linear movement from point A to point $\mathrm{B}$, it is better to conceptualize their sense of belonging to the queer community as "cultural citizenship", or a series of uneven negotiations. These negotiations take place on both an interpersonal or intergroup level, when groups or individuals negotiate belonging to a larger community, and also on an intrapersonal or intra-group level, where individuals negotiate and attempt to resignify their identities. The most important aspect we can take from this literature review is that, in negotiating cultural citizenship, as well as "belonging", queer migrants, and indeed all members of the queer community, are also involved in the negotiation of identity. It is important to note that the performativity of both individual and group identities means that it is never possible to totally subvert identity constructions, nor is it possible to unilaterally "claim" citizenship and completely undo the boundaries of any 
community. However, this does not mean that communities are necessarily fixed or rigid. Rather, the negotiation of identities and cultural citizenship can also be used to "queer" the notion of community itself, constructing it as a process in need of continuous negotiation and resignification. Performances can act as an important avenue for introducing the counter-discourses that lead to the re-negotiation of community, belonging, and identity.

\section{Pride Week 2009 and the Politics of Belonging}

\subsection{Introduction}

Citizenship is about more than naturalization. As Ong (1993; 1999) and Rosaldo (1994; 1999) argue, culture is central to informal citizenship and a sense of belonging, and is often a key indicator of who can be considered a citizen and who an outsider. This chapter will examine Luka's performance as an act of "cultural citizenship". As Ong (1999) argues, cultural citizenship is a series of uneven negotiations within hegemonic power relations, where cultural citizens are shaped. This chapter will seek to map the webs of power that act to discursively shape and police belonging in the queer space of Toronto Pride Week and in the Toronto queer communities more generally. Thus the citizenship that will be examined is a queer citizenship and a sense of belonging to a queer “imagined community” (Frolic 2001; Anderson 1983). Luka's performance will then be discussed as an important site of resistance to forms of cultural inscription that position certain queer identities as culturally queer and others as outsiders. This chapter will evoke a Foucauldian (1989) sense of "subject-ification", of "self-making and being made" within webs of power (Ong 1999, 263-264). I will argue that Luka's performance acts to express the in-between space and multiple ambiguities of a life in transit. Luka's 
performance is representative of the ambivalence of identity and community in general and the vacillating desire for belonging within a disconnected network of connected people. This chapter will draw on data gathered in the participant observation component of the research, as well as, my discussions with Luka.

\subsection{You Belong: The Politics of Pride 2009}

...And when we as people of colour and immigrants speak, we speak with our voices, and our bodies, and our experience. Often we get demonized. You know we are all used to the tokenism; put them at the front of the parade! But when you want to talk about sharing power, well that's a different issue....

- El Farouk Khaki, Toronto Pride Week's 2009 Grand Marshal, at the Global Human Rights for Queers panel discussion held at Isabel Bader Theatre, June 22, 200921

For queer people who are new to the city, province, or country, annual Pride Week celebrations often serve as a point of contact with the queer community in Toronto. Queer youth and those who are recently "coming out" often experience a sense of queer community for the first time at Pride Week. Toronto Pride Week is central to this study, not only because it is the site of the particular performance piece that this analysis will focus on, but also because it was at Toronto Pride Week where Luka first performed in Canada and where he had one of his first experiences with queer life in Toronto after moving here in 2003. Therefore, it is important to understand the ways in which the events and politics of Pride Week contribute to the discursive shaping and bounding of the Toronto queer community. This section will examine some of the discourses and counter-discourses of Toronto Pride week, the power relations between various queer groups that these discourses are embedded in, and how they contribute the production of queer knowledge, as well as the reification of certain queer identities and exclusion of others. By analyzing the politics of belonging in the Toronto queer community, this

${ }^{21}$ See http://www. youtube.com/watch?v=B3M45SkPaQY\&feature=channel page $($ Accessed 07/02/09) 
section will consider the "dirty work of boundary maintenance" (Favel 1999, 209-227). I will argue that the space of Toronto Pride Week is an ambiguous space, marked by hegemonic power relations that structure queer belonging in an exclusionary way. I will also argue that there are multiple sites of resistance to this exclusion. This section will draw upon data gathered in the participant-observation component of the research.

In 2009 “official" Pride Week events spanned from June $19^{\text {th }}$ to June $28^{\text {th }}$. Here "official" means those events endorsed by Pride Toronto, the not-for-profit organization governing Pride Week ${ }^{22}$. The theme for Pride Week 2009 was, "Can't Stop, Won't Stop". This "official" theme was displayed at various Pride events, marking the space as "official" space. The implicit narrative embedded in the theme of "Can't Stop, Won't Stop" is one of a queer rights movement, a struggle and/or fight, a linear progression that necessarily continues. The phrase is somewhat ambivalent, with the goal of this movement left open for question. Yet it appeared most often in Pride pamphlets and events in conjunction with a focus on global human rights for queers, and was explicitly tied to this focus in the "Director's Welcome" of the 2009 Pride Guide (Pride Toronto $2009,8)$. A focus on global human rights for queers provides an issue for the community to potentially rally around in solidarity. Indeed, it is always easiest to unite large and diverse groups of people in solidarity when there is a common goal to fight for (Bhabha 1994, 149). In the past, the queer community in Toronto has shown considerable strength in unity when rallying around issues such as the bathhouse raids of 1981, the AIDS epidemic or the fight for same-sex marriage rights (Frolic 2001). However, at the Global Human Rights for Queers panel discussions held at the Isabel Bader Theatre and the

\footnotetext{
${ }^{22}$ There were smaller, localized community events celebrating Pride "month" as early as two-weeks prior to the official opening party ceremonies, including the City Toronto Youth Services production of Genderplay.
} 
Gladstone Hotel, several local queer people of colour and queer refugees at the event voiced the opinion that much of the narrative of global human rights is embedded in a Eurocentric discourse which prizes the West and positions non-Western queer identities as less than liberated. The same speakers were quick to remind those in attendance that there are still forms of oppression that permeate the queer community, including racism and transphobia, which marginalize certain queer people even within the community space of Pride Week. Already, from this one event we can see that it would be overly simplistic to read Toronto Pride Week as a unified expression of queer identity. Nor would it be appropriate to view the people involved as members of a singular queer community. Even though it is frequently referred to as "our community" or "the community" (Pride Toronto 2009), it is more useful to conceptualize queer space as a network of smaller groups, organizations, communities and scenes, some of which overlap and others that are quite disconnected, all of which are situated differently within hegemonic power relations.

Several scholars have argued that within Toronto queer space, white, gay, upper and middle-class men are the dominant group, the most visible, with the most access to power (Silvera 1990; Fung 1991; Gay Asians Toronto 1996; Nash 2005, 5; Pendleton Jiménez 2005; Sears 2005; Walcott 2006; Betancourt 2009). This group is representative of the queer mainstream, the group that most Pride Week events are geared towards, and the group that claims the most space at Pride Week. To counter the male hegemony of Pride Week, the Dyke March was added as an annual event in 1996 (Frolic 2001, 280). In 2009 the first ever Trans March was also added. At Pride Week 2009 there was also the TransAction stage, specifically featuring trans performers. As Frolic (2001) argues, 
"presumably women [and trans people] would not take to the streets independently if they felt their political and ideological needs were adequately met in the Pride Parade" (280). Women's exclusion and invisibility is further evident in the geography of the Church and Wellesly village, and indeed most gay villages in North America and Europe, where most of the business are owned by and cater to gay men (Wolf 1980; Valentine 1989; Adler and Brenner 1997; Podmore 2001). In Toronto this means that out of the myriad of bars and nightclubs that populate the village, only one bar, Slacks, is explicitly a lesbian bar. In addition, only one other bar, Voglie's, seems to attract a significant number of women as customers. There are no bars or night clubs specifically for trans people in Toronto, although Goodhandy's, which is located on Church Street but outside of the village, hosts weekly trans nights.

Communities of racialized queer people, as well as, communities of queer immigrants and refugees have created their own spaces in opposition to the white dominated space of the Church and Wellesly village (Gay Asians Toronto 1996; Pentledon Jiménez 2005; Walcott 2006). These spaces range from advocacy groups, such as Gay Asians Toronto, to creative writing groups, such as Lengua Latina (Gay Asians Toronto 1996; Pendleton Jiménez 2005). At Pride Week specifically, there were independently organized stages that showcased performers from these communities including; Blockorama, a stage featuring black queer performers and Funk Asia, a stage featuring queer South Asian performers; as well as, smaller shows off of the main stages including; Colour Me Drag: Colour Me Pride, featuring drag and burlesque by performers of colour and Queer Asian High School Musical, featuring East Asian youth performers. Refugee Pride, a support group for queer refugees also held its own pride 
party and film screening. There are bars and nightclubs in Toronto that feature nights for queer people of colour, including the weekly Fresh To Def parties at the Gladstone Hotel as well as, drag nights at the latino bar, Il Convento Rico. It is important to note that both of these bars are located outside of the Church and Wellesly village which means that space for racialized queer people may be just as (or more) invisible as space for queer women. Within the mainstream gay bars and nightclubs in the village, many racialized queer people and queer immigrants find themselves fetishized by white queer people who view them as the exotic other (Fung 1991; Gay Asians Toronto 1996). For queer immigrants and refugees, particularly those who are women or trans, finding a place to belong in what is known as the queer community, means navigating this often dislocated and fractured space. The invisibility of many racialized or immígrant queer communities and queer women's spaces, can make for a particularly isolating period of integration (Gay Asians Toronto 1996).

Another significant factor shaping Toronto Pride Week and the Church and Wellesly village has been the increasing effects of the "gay dollar" and increased corporatization. As Alan Sears (2005) argues, "open lesbian and gay life has thrived primarily in commodified forms: bars, restaurants, stores, coffee shops, commercial publications, certain styles of dress and personal grooming, commercialized Pride Day celebrations with corporate sponsorship" (104). During Pride Week 2009, corporatization was evident in the wide array of corporate sponsors, but perhaps more disturbingly, on the bodies of Pride goers, in the form of free temporary tattoos that stated "Proud" above a Pepsi symbol or free green sunglasses with the TD Bank logo, that nearly everyone seemed to be wearing by the end of the week. Class divisions were also apparent in 
increased cover charges, as high as $\$ 15.00-\$ 30.00$ at most bars and night clubs, special Pride Toronto passes that could be purchased to gain entrance to the main stages without waiting in line, and the annual Gala and Awards dinner with $\$ 325.00$ tickets. Sears (2005) argues that, "a community structured upon commodified public spaces is economically exclusive" (105). Queer women are particularly affected by the commodification of queer space, because of a gendered division of labour that positions most women in a lower economic standing than most men (Sears 2005). Queer immigrants and refugees may also be particularly affected by commodification as immigrants and refugees in general are often in lower economic standing than the Canadian-born due to the time that it takes for economic integration ( $\mathrm{Li} \mathrm{2003,104).} \mathrm{In}$ terms of cultural integration, it could be very difficult to find a sense of belonging in a community whose lifestyle you cannot afford.

Despite the invisibility of many queer identities, and the multifarious groups, organizations, and small communities that comprise queer space in Toronto, those with the power to shape the queer space of Pride Week, mainly Pride Toronto, continue to structure this space under the guise of a single community. This is evident in the 2009 Pride Guide where a singular queer community is continually referred to (Pride Toronto 2009), and also in attempts to create solidarity around a single issue, as discussed above, rather than engaging in coalition building with smaller queer groups, around various issues. The notion of queer solidarity can also be read in Pride Toronto's 2009 marketing campaign. The slogan for Pride Toronto's 2009 marketing campaign was "You Belong," which most notably appeared on billboards (See Figure 1), but also on Pride Toronto brochures and banners displayed at "official" Pride Week events including the Global 
Human Rights for Queers panel discussion on June $22^{\text {nd }}$. Embedded in this billboard and slogan are some powerful indicators as to exactly who belongs in the space of Toronto Pride Week. In order to understand the effect or desired effect of the slogan it is useful to

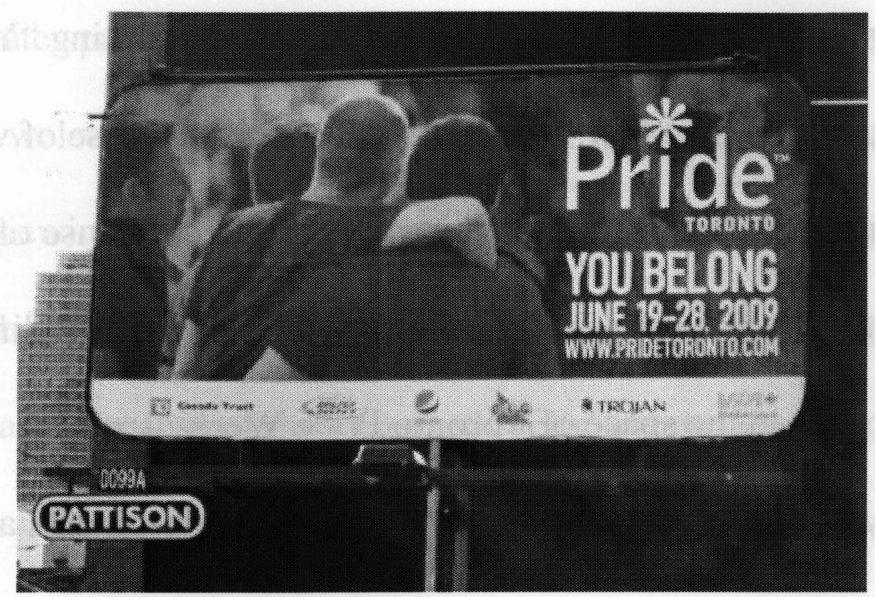

Figure 1. Pride Toronto billboard on the north-east corner of Church Street and Shuter Street.

turn to Butler's (1997) discussion of performative speech acts. Butler (1997) draws on J.

L. Austin (1975) who argues that language is used for more than just the simple conveyance of facts. Austin (1975) demarcates "constative" speech, statements that can either be true or false, from "performative" speech, statements that are used to perform an action. It would make little sense to judge the statement "You Belong" as either true or false, rather it was likely chosen as the slogan for Pride Toronto's 2009 marketing campaign because of the intended effect it would have on its audience. Butler and Austin further distinguish between two types of performative utterances, the "illocutionary" speech act, which "is itself the deed that it effects", and the "perlocutionary" speech act, which "leads to certain effects that are not the same as the speech act itself" (Butler 1997, 3). Illocutionary speech acts are highly dependent upon the context in which they are said, and are usually ritual or cultural performances, for example saying, "I do" at a wedding ceremony or "I bet you..." while gambling. These statements are effective only 
because they are recognized as performing a certain action within a given society or culture (Butler 1997). Perlocutionary speech acts are statements that are said in order to produce a certain effect (Butler 1997), and are commonly used in advertising and marketing as a form of persuasion (O'Shaughnessey 2004). Stating "You Belong" is not stated in order to convey some fact, rather it is stated for the sense of welcoming it will effect in its reader. "You Belong" is stated in order to effect a sense of community, by bringing together the multifarious "yous" at whom the statement is directed and causing them to feel welcomed in the space of Toronto Pride Week.

However, as Butler (1997) argues perlocutionary speech acts are highly dependant on the context in which they are said, and can often produce effects that were not necessarily intended. Thus, one utterance could have numerous perlocutionary effects (Butler 1997). In contextualizing the "You Belong" slogan, it is important to pay attention to some of the non-verbal message components that surrounded it. The image that most often appeared with the slogan is of two white men in a crowd of people who have been washed over with rainbow colours. Because two men in the centre are the only ones not washed over with colour, and it is clear that they are the intended subjects of discussion. The relationship between the two men is somewhat ambiguous, they could be read as yet another reification of the respectable same-sex couple (Valverde 2006), or with a more queer reading they could be two buddies "cruising" a crowd of rainbowcoloured men. This ambiguity was likely intentional in order to attract the largest audience possible. At the bottom of the same billboard is a series of corporate logos representing the major sponsors of Toronto Pride Week. It is reasonable to expect that anyone who sees this billboard and personally identifies with its symbols, the same-sex 
couples, the gay men, the rainbow colours, will read the slogan and feel welcomed at Toronto Pride Week. However, the same image could have an entirely different effect. The viewer who sees this billboard, and who recognizes that in the white, male dominated, corporate space of Pride Week, their queer identity is often excluded, may feel left out or not welcomed. This person would not feel a sense of solidarity or welcoming upon viewing the billboard. Instead the billboard would function as more of a cruel joke. This other(ed) viewer is supposed to "belong" by virtue of being queer, but does not in most cases because of their race, ethnicity, gender identity, disability, class, or immigration status. The image of the two white men was likely chosen in an effort to appeal to the widest audience possible, as white, gay men make up the majority of the constructed, hegemonic queer community and because in adopting "whiteness" and "maleness" a certain neutrality is awarded. Bérubé (2007) calls this type of representation, "shielding" the queer community under a "pale protective." The presumptuousness of this extension of belonging, in conjunction with the collapsing of subjectivity into a neutral, singular "we group", is unlikely to resonate with those who have "never felt solidarity with the representers of the self-image of [in this case, queer] society" (Code 1993, 22-24). If belonging is a major component of cultural citizenship, then achieving cultural citizenship in the queer community, as represented by this image, is contingent upon assimilating to a white, gay male, middle or upper-class identity, or constantly living in its shadow.

As stated, several groups of people are invisible within the "You Belong" billboard. This is however, not only a matter of billboards. The discourse embodied in this billboard is representative of a broader queer politics. The ultra-visibility and power 
of white, gay men within the queer community means that the discourse presenting the same white, gay men as the quintessential queer identity is one that circulates and recirculates throughout the queer communities and space. Lisa Kaheleole Chang Hall (1993) argues that the politics of solidarity building will always rely on ignoring or excluding differences. She argues that coalition building, in which there is recognition of differences, as well as acceptance of the fact that in building a coalition you will get hurt, is a more politically useful way to maintain the momentum of the queer movement while recognizing each others differences (Chang Hall 1993). Similarily, Iris Marion Young (1986) argues that creating a recognizable community means separating out the other. She draws on Derrida (1974) to argue that, because the other is always already an aspect of the self, the bounding of a discrete community is impossible, and communities will always remain fractured. Thus, assumptions of solidarity will always backfire and serve to highlight the differences of community instead, when these repressed differences "surface with a vengeance" (Chang Hall 1993). The space of Toronto Pride Week is a fractured and ambivalent space, writ upon with hegemonic power relations that ultimately position white, gay men as the acceptable queer citizen. The power of the white, male, queer subject is circulated through and reified in the discourse of Pride Week, as can be seen in the example of the "You Belong" billboard. However, new queer identities and collaborations are continually "surfacing" in the space of Toronto Pride Week to challenge the hegemony of this exclusive queer identity and conception of Toronto queer space as a single community. It is these challenges to which the discussion will now turn. 


\title{
4.3 Breaking the Fourth Wall ${ }^{23}$ : Ambivalent Performance and Performative Identity
}

\author{
Wind tugging at my sleeve \\ feet sinking into the sand \\ I stand at the edge where earth touches ocean \\ where the two overlap \\ a gentle coming together \\ at other times and places a violent clash \\ - Gloria Anzaldúa, "El Otro Mexico" in Borderlands, La Frontera, 1987 pg. 28. \\ But each day when she goes to the sea \\ She looks straight ahead not at me \\ - Frank Sinatra and Tom Jobim, "The Girl from Ipanema"
}

The previous section described some of the cultural inscriptions of power that shape and police belonging in the Toronto queer community. These discussions have attended to what Ong (1999) calls, "a Foucauldian sense of being-made by power relations" in the negotiation of cultural citizenship (263-264). It would of course be naïve to read the various sites of counter-hegemonic discourse in any community às equal force to the ideologically powerful forces that attempt to bound and shape community. As Ong (1999) points out, these are negotiations embedded in an uneven set of power relations. At the same time, there is not only one site of counter-hegemonic discourse, there are many sites, some overlapping, all situated differently in relation to the dominant group. As was discussed above, to read Toronto Pride Week as a unified expression of queer identity would be overly simplistic and would only reinforce the discourse of a dominant queer identity. This section will turn to the some of the sites of resistance that surfaced at Toronto Pride Week 2009 in order to examine more closely these processes of negotiation and the effects they have on the spaces in which they occur. Though there

\footnotetext{
${ }^{23}$ I owe the title of this section to the wit and wisdom of the great drag queen Rupaul who wrote, "In theatre, there's a term called 'breaking the 4th wall'. It's when an actor drops character and addresses the audience. The other actors on stage hate it because it immediately breaks the illusion that what's happening on stage is really real. The animosity that drag queens experience by society at large is due to the same scenario. People get angry when the role they're playing is revealed to be nothing more than an illusion. When the hoax is revealed, their ego instructs them to retaliate and discredit the rogue player who broke the 4th wall." See http://www.rupaul.com/news/2009 0301 archive.html (Accessed 07/02/09).
} 
were many sites of resistance that were observable at Toronto Pride Week 2009, I will focus mainly on Luka's performance at Colour Me Drag: Colour Me Pride. Luka performed at many different events during Pride Week, several of which could be described as sites of resistance to dominant queer space, but in order to focus on the nuances and ambiguities of performance as resistance, only the one performance will be discussed in detail. This section will draw on themes that arose in my discussions with Luka about his performance at Colour Me Drag and about performance and Pride Week more generally, including; working with identity, the ambivalence of "home", the significance of in-between space, and the idiosyncrasies of a life in transit.

The Colour Me Drag: Colour Me Pride main event ${ }^{24}$ took place at the Gladstone Hotel on the Monday of Pride Week, June $22^{\text {nd }} 2009$. Though not located in the traditional gay village of Church Street, the Gladstone Hotel is located in another recently established gay area in Toronto on Queen Street West, known locally as "Queer West." This year, some events at the annual Queer West Fest were held in conjunction with Toronto Pride Week, including the Global Human Rights for Queers panel discussion that was briefly discussed above. Queer West has been widely criticized for contributing to the gentrification of Queen Street West that is continually encroaching on the lowincome neighbourhood of Parkdale (Graham and Roemer 2007). Queer West has also made public efforts to distance itself from the "ghetto mentality" of the Church and Wellesly village (Peesker 2009). The Gladstone Hotel in particular has been criticized as bourgeois space, claimed by the middle classes to the detriment of the abject poor who were pushed out of that space (Graham and Roemer 2007). Others have argued that

\footnotetext{
${ }^{24}$ Colour Me Drag also had a time slot during Pride Weekend, on the Village Drag stage as well as the TransAction stage, where Luka also performed.
} 
Queer West has become a valuable space for those who feel left out in the mainstream space of Church and Wellesly, including queer women, racialized queer people, queer youth, and new queer identities (Peesker 2009). I am skeptical of a romanticized view of Queer West as a new queer haven, yet the Gladstone Hotel in particular seems to have become a space used by queer people of colour, hosting weekly Fresh To Def parties, organized by and for queer indigenous people and people of colour.

The Colour Me Drag: Colour Me Pride event was described in the 2009 Pride Guide as, "Toronto's finest performers of colour, representing all walks of life and all performance history. We aim to empower and inspire!" (Pride Toronto 2009, 17). In discussing his performance at Colour Me Drag, Luka noted that,

One of the visions of Colour Me Drag is that performers of colour [...] have a space to perform pieces that they wouldn't necessarily feel comfortable performing in other spaces, so maybe it's a piece in Portuguese or Spanish that you wouldn't feel comfortable going to Crew's \& Tango's ${ }^{25}$ with because it would be lost on the audience, and also to create a community and connections between performers of colour.

The performers themselves made up a wide range of ethnicities and queer identities, though both the performers and audience members at Colour Me Drag and the weekly Fresh To Def parties tended to be younger (in their 20s and 30s) in comparison to mainstream Pride Week events where middle-aged queer people make up the majority. The use of the word "Me" in the name, Colour Me Drag: Colour Me Pride is significant in relation to the assumed solidarity of "You Belong", as discussed earlier. It acts as a reclamation of the subjective voice and a discursive assertion of agency. In this sense,

\footnotetext{
${ }^{25}$ Crews and Tangos is a popular Church Street bar, one of few that seems to draw both gay men and lesbians, which regularly hosts drag performances during Pride Week and throughout the year.
} 
Colour Me Drag: Colour Me Pride is an oppositional group speaking, through drag, for themselves, in contrast to the speaking for others that is embodied in "You Belong". Thus, it is a statement that challenges the imagined unity of the "queer community".

In focusing on the intersections of queer and ethno-racial identities, the event itself acted as an important site of resistance to the white dominated queer space of Toronto Pride week. As Hall (1992b) argues, while the essentialization of identity was at one time politically useful in creating solidarity, it is now necessary to resist essentialization and instead focus on the intersections of identity as no community can be understood as homogenous. I would argue that the assimilatory politics and essentializing discourse within the queer mainstream have made Hall's (1992b) call to examine the intersections of identity all the more urgent for queer-politics. Furthermore, Homi Bhabha (1994) argues that projects focusing on the articulations of difference produce "theoretically innovative and politically crucial" third spaces where new signs of identity are initiated and "innovative signs of collaboration and contestation" are instigated (2). With a mix of serious themes, such as spoken word pieces questioning race-based injustices and more campy drag pieces, as well as erotically charged burlesque pieces, Colour Me Drag served to highlight what Walcott (2006) calls, the "pleasure and pain of hybridity" (129). The event acted as a chance to work through and over the concepts of “community", "identity", and "desire".

One of the most important, and indeed powerful aspects of Luka's performance is that it draws on personal material and works with and through identity. This is a common theme in Luka's body of work as a "non-artist". As Luka mentioned in our discussions, 
That's where I get a lot of my pieces. They are about the intersections of identity. For example, when I was talking about immigration, it was about being queer and an immigrant.

Bornstein (1994) argues that performances that focus on identity and "self-discovery" have the potential to challenge cultural assumptions by exploring the messiness and complicatedness of everyday life (160-165). By focusing on "self-discovery", performance pieces also have the potential to affect inter-personal change or transformation in the performers themselves. Escudero-Alías (2009) alludes to this when she states that many drag performers use the stage as a "safe space" to explore gender identity (77). Though these changes may be small and though they may be very localized, affecting only the performer, they do present some challenge to cultural conscriptions of identity. In our discussions about gender identity, Luka noted the affects that his past performances have had on his identity,

It's funny because when I tell my trans "coming out" story, I always go back to my performances $[\ldots]$ I was part of this young, girls theatre group $[\ldots]$ not surprisingly I came up with two very gendered pieces. One of them was about this girl $[\ldots]$ who runs away from home and she is going through a desert, a magical desert, where she begins to transition to male [...] But I was just writing a piece, I was not aware at all and then afterwards all of my friends started coming up to me saying, "what's up?" and, "what's happening?" and I was like, "hmm, maybe there is something more there..."

Luka's trans "coming-out" story is interesting because it speaks not only of a performance focusing on "self-discovery", but significantly "self-discovery" through performance. It also speaks of an embodied knowledge, of knowing the self through the body before reaching the same conclusion with the conscious mind, and thus challenges 
positivist thought where deductive-logic offers the only path to knowledge. Thus, performances that focus on "self-discovery" can also serve to question the concept of "knowledge" itself. Positivist thought is often positioned as "civilized", "Western" and "masculine", superior to the knowledge systems of the rest of the world. Performances that focus on identity and "self-discovery" can therefore offer a means to challenge dominant discourses and, to extend Lorde's (1984) metaphor of the master's house, do so without using the "tools" of those in power.

I will begin this analysis with Luka's description of his performance. I will then go into a more in-depth consideration of some of the themes of Luka's performance as identified by Luka in our discussions.

I call it a gender-fucking performance because it is not.necessarily drag and it is not necessarily burlesque, it is something weird in-between. The song was "Girl From Ipanema" sung by Frank Sinatra and Tom Jobim, so it was bilingual, in Portuguese and English. I walked on the stage in female "drag"...I had a Brazilian flag and I put it on the ground as a beach towel... and then I started to undress [into a bikini] ... then I sat on the flag, looking at the audience... At some point I started walking away from the towel, the flag... and I started dressing again but this time with male clothing... Then I sat in the chair, which was stage right...I was lip-synching the song... looking at the flag...

In explaining his intentions in creating this particular performance piece, Luka stated that, I am from Brazil and as a female a lot of times what people would say to me was, “Oh, Girl from Ipanema!" and I hated that. I never identified as a girl from Ipanema. First, I am not from Rio, I am from São Paulo [...] I never identified as a girl really and definitely when I went to the beach I didn't act like a girl from Ipanema... Then one day I was listening to the song and the lyrics pretty much say something like, the girl who walks past and she doesn't look at me or 
see me, and I thought that had a lot to do with gender issues. People who pass,

they often don't see you, either because you pass as the gender you want to be,

or because they just don't see the struggles that you are going though.

In presenting some interpretations of Luka's performance, it is important to remember that all interpretation is a negotiation between the viewer and the performance, and is highly dependant on the viewer's awareness or unawareness of the particular social and cultural codes that the performer is drawing on (Hall 1980). Interpretations of Luka's performance would likely vary from person to person, based on the viewer's social positionality and values, the time and place that it was performed in, among numerous other factors (Hall 1980). The interpretations presented here should therefore not be read as a comprehensive list of all the various ways that this performance could be interpreted, nor should the performance be read as possessing an overarching and singular meaning. Rather, this subsection will focus on a few, sometimes contradictory and ambivalent interpretations of Luka's performance that have implications when considering the negotiation of cultural citizenship for queer immigrants into a network of groups and smaller communities collectively known as the "queer community".

One of the most subversive elements of Luka's performance is that it resists the signification of a genre. As Luka noted above, his performance sits irresolutely between drag and burlesque ${ }^{26}$. Luka addressed this enigma several times in our discussions, Is this drag? What is drag for me at this point? In a lot of performances I do end up playing with both male and female roles [...] Even the definition of drag [is

\footnotetext{
${ }^{26}$ Ross $(2002,382)$ briefly discuses a neo-burlesque movement emerging in North America that endeavors to recuperate and re-stage the "tease-factor," as well as, the glamour and the mystery of female sexuality. I would argue that there has also been a movement to deconstruct hegemonic forms of male sexuality through male burlesque acts, such as Toronto's Boylesque troupe.
} 
political], there are a lot of trans-identified men who are drag kings. Is that even drag?

The definition of drag is indeed contentious. In discussing drag kings, Escudero Alías (2009) defines drag kings as women or FTM transgendered ${ }^{27}$ people who perform a parodic and theatrical masculinity on stage (61). She goes on to argue that there are no transsexual ${ }^{28}$ drag kings (Escudero Alías 2009, 66-67). Escudero Alías' (2009) assertion that there are no transsexual drag kings, suggests that only those who are female or who retain some elements of a female body, can perform drag and that anything else is a mimicry of hegemonic structures of masculinity. What this demonstrates is that even something as inherently queer as drag, can become bounded by a rigid "straightness." This definition of drag does little to destabilize a rigid gender binary as it continues to be dependant on this binary in its delineation of who is and who is not a drag king. Luka's performance is queer in that it fucks with the "straightness" of typical conceptions of drag. This is because Luka's body also refuses to be signified, labeled, or fixed. Unlike the performances discussed by Walcott (2006) and Escudero-Alías (2009) in the previous chapter, Luka's gender identity is never really made clear to the audience. Rather, it is made queer. Luka identifies both of the genders that he adopts on stage as drag,

I would say that me walking on stage in a bikini [...] is drag because I don't identify as female and I am wearing female clothes, but I didn't play it up. I was not wearing makeup, I was not wearing a wig, I did not shave. I think that is quite queer.

\footnotetext{
${ }^{27}$ A transgendered person is someone who identifies with a gender other than the one they were prescribed at birth, who lives as that gender, but who decides, for whatever reason, not to undergo a full sex change.

${ }^{28} \mathrm{~A}$ transsexual person is someone who identifies with a gender other than the one they were prescribed at birth and who has undergone, or plans to go through a full sex change operation.
} 
Luka's male performance also sits in contrast to drag king performances that valorize passing,

Some places where drag is performed, you have to bind, you have to pack, you have to have facial hair...

By refusing to complete both of the gendered illusions performed on the stage, Luka makes it difficult for the audience to be sure which of the performed genders is drag, as both appear to be. If both of the genders on the stage are imperfect performances, then the idea of a natural gender beneath the costume is thrown into question. In this way, Luka's performance problematizes drag and subverts the discursive bounding of gender, not by pointing to its limits, as Walcott (2006) has argued in his discussion of the subversive elements of drag, but by pointing to its ambivalence. By demonstrating the ease with which one gender can morph into the other, Luka's performance also demonstrates Derrida's (1974) argument that the "other" is always already an aspect of the self. Thus, Luka's performance points to the problematic aspects of singular and fixed conceptions of identity, as well as, the notion of a unified and discretely bounded community (Young 1986, 3).

One of the main cultural symbols that Luka's performance plays with is the "girl from Ipanema", the exoticized image of Brazilian women. Luka plays up this exoticization and exaggerates it when he lays the Brazilian flag out like a beach towel, setting the scene for the first half of his performance (See Figure 2). As Daniel Gawthrop (2005) argues in The Rice Queen Diaries, the beach exists as a powerful cultural symbol for the erotic and the exotic (117-118). The symbol of the beach as both erotic and exotic 


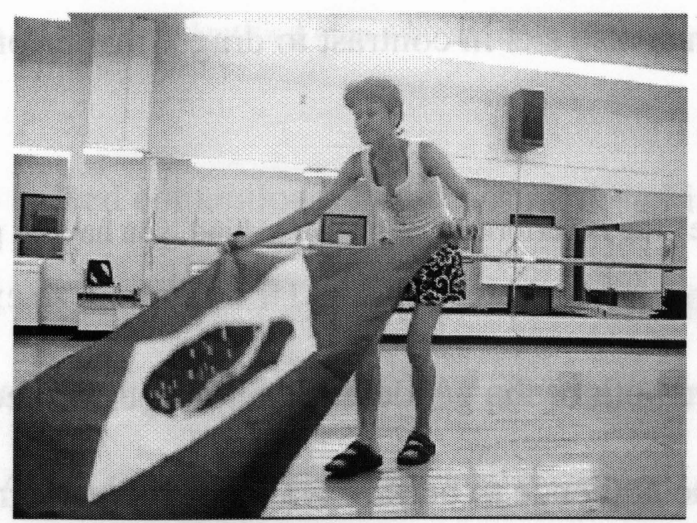

Figure 2. Using the flag as a beach towel

is one that is commonly circulated throughout popular culture. It is evident in popular films, such as Danny Boyle's The Beach (2000), starring Leonardo DiCaprio, about a young man from the West who discovers sexual adventure on the beaches of exotic Thailand (Gawthrop 2005, 117-119), as well as in popular erotica, such as the Sports Illustrated Swimsuit magazines and calendars, which display a series of mild, erotic images of women in bathing suits on various exotic beaches around the world, including Ipanema in 2007. Luka begins his performance with this image, using it in conjunction with the strip-tease to grab the audiences attention and entice them into taking pleasure in the performance and in the exoticized "other." Luka then problematizes the image of the exotic by making it queer, which he accomplishes by refusing to complete the gendered illusion and by pointing to the ambivalence of gender, as discussed above. In doing so, Luka's performance undermines the authority of this exoticized image. Luka simultaneously problematizes the audiences' desire for the exotic by disavowing them the completed image and then re-dressing into another incomplete gender. By re-dressing, specifically as male Luka re-claims the active role typically denied to the exotic or the feminine and escapes the audiences fetishistic gaze (Mulvey 1975). Because the male image is also incomplete and still contains some elements of the feminine, he throws into 
question the binary conception of male agency and female passivity, as well as, the binary conception of the West's agency and the exotic "other's" passivity.

Luka's use of the flag is also connected to the concept of multiple homes. Luka evokes exile and a home left behind when, in male drag, he gazes longingly at the flag he has just left behind, representing the country he has also left behind.

I think that the Brazilian flag in a way is what the piece is about [...] I look at the flag... it could be my male self, which is in Canada now, looking back at that female version of myself... the song has that feeling of missing... missing the girl from Ipanema, sort of longing for something that is in the past. So there is a bit of looking back from my male self to my female self and missing it a bit, but at the same time, not wanting to go back there. Because of the Brazilian flag, it is also about home and missing home. My female self and Brazil are, for me, interconnected.

In Luka's performance home and desire are inextricably intertwined, marking the queer space of the Gladstone Hotel as a site of "homing desire". Adi Kuntsman (2007) describes sites of homing desire as, "a mythic place of desire in the diasporic imagination" (146). For Kuntsman (2007), the creation of sites of homing desire are integral to queer immigrants desires for a place of their own, for belonging on their own terms, and are representative of a movement between integration and separation (145147). In the previous chapter I drew on Fortier (2001) to argue that integration could be better understood as a negotiation or as an oscillating movement between home as an origin, home as an inhabitation, and sites of homing desire. Luka's performance can therefore be seen as a site of this negotiation, as precisely this movement. At this point in the performance, while Luka is looking back, he is also noticeably comfortable, leaning leisurely in the chair. Luka's retrospective gaze is from a place of home-like comfort. 
Thus, the "home" evoked is a multiple "homes". Luka also expresses multiple homes in our discussions when I ask him where home is for him,

I think I have two homes because Toronto has become my home. My friends are here, my parents, my close family members are here [...] I have a lot of memories in Toronto now [...] But at the same time I think that Brazil is home [...] Probably because, again I have memories there, and because that's where I have spent most of my life at this point. And then there is the whole cultural aspect... I have two homes.

During Luka's performance these homes are both represented on the same stage. This acts to challenge traditional immigration narratives that construct originary home and exilic home as neatly bounded and spatially isolated from one another (Fortier 2001). It is also interesting to note that in Luka's performance these "homes" take on more than a geography. They also take on a gender identity. In this sense, Luka's queer and trans identities are positioned as not easily separable or isolated from his Brazilian identity. This points to the consequential role of subjective identity negotiation in the integration process. It also points to identity as something always incomplete, continuously in negotiation, as it, too, moves between "homes" and belongings.

In problematizing notions of gender, desire, and home, Luka's performance speaks from the liminal space of the, "minority, the exilic, the marginal and the emergent" (Bhabha 1994, 149), but also from the borderlands of "the perverse, the queer, the troublesome, the mongrel, the mulatto, the half-breed, the half dead; in short, those who cross over, pass over, or go through the confines of the "normal"' (Anzaldúa 1987, 25). As Bhabha $(1994,2)$ argues, “these ‘in-between' spaces provide the terrain for elaborating strategies of selfhood - singular or communal - that initiate new signs of 
collaboration, and contestation, in the act of defining the idea of society itself." Speaking for and from this in-between space, Luka's performance is an act of "self-making" in contest to the essentializing discourse of Toronto Pride Week. In our discussion of his performance, Luka and I agreed that this in-between positioning was one of the most important elements of his performance. In consideration of the photographs I had taken of his performance, Luka directed my attention to the symbolism of the in-between spaces in his performance (See Figure 3),

I think [this photograph] is symbolic of my performance...I am wearing the bikini top and the shorts... That is what I wanted to do... I wanted to create an in-between space... I think that was a crucial moment in this performance.

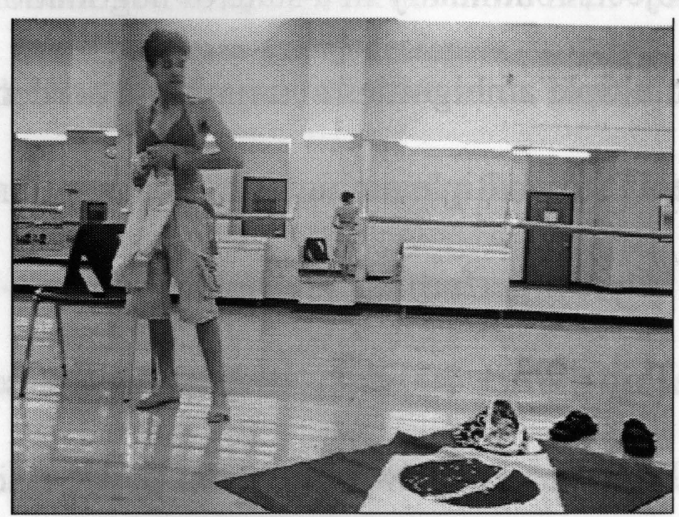

Figure 3. In-between space

In reflecting on Luka's performance, I think that this photograph is symbolic of a borderland aesthetic (Anzaldúa 1987), in that Luka is positioned between "homes" and between "genders". The flag on the ground as a beach towel also works with Anzaldúa's (1987) metaphor of the beach as an in-between space between land and sea (28). Luka's positioning speaks of a sense of incompletion, as Luka noted,

I think that liminal spaces have a very specific set of rules that are different from the outside world...Y You have a very specific reason to be there and in a lot of ways you are waiting for something else to happen. 
Consequently, "gender", "home", and by extension "belonging", are signified as always incomplete processes, rather than pre-constituted entities.

When I asked Luka for an example of a liminal space between Brazil and Canada, he replied without hesitation, "an airplane". Beneath the simplicity of this statement is an important conceptualization of in-between space that positions the body as in motion, or in transit. Luka's performance also evokes the idea of a body-in-motion as he moves between genders and between homes. The movement in Luka's performance, from the flag to the chair and back to the flag through the gaze, or from female to male and back to female under the gaze, represents the vacillating ambivalence that signifies belonging as an always unfinished project, continually in a state of negotiation. In doing so, Luka's performance speaks of multiple ambiguities and multiple border crossings. I would argue that performances that point to multiple ambiguities and position the body as "in-motion" are emerging strategies in queer performance. Another example of this type of performance at Toronto Pride Week 2009 was drag queen Chris Edwards' ${ }^{29}$ portrayal of Michael Jackson in the Pride Parade. Edwards' performance also points to multiple ambiguities, for what meaning can be derived when a black female transsexual, well known for her "white face" drag queen performances, performs as a black man with an ambiguous gender identity and an ambiguous racial identity? Like Luka's performance, Edwards performance of Michael Jackson is not easily classified as drag. Rather, it positions the body-in-motion, oscillating between various gendered and racial identities. The ambivalence of identity can also be found in contemporary transnational literature, such as Mary Anne Mohanraj's (2006) book of short stories, Bodies in Motion, which

\footnotetext{
${ }^{29}$ See the previous chapter and Walcott (2006) for a discussion of Edwards' "white face" drag performances.
} 
positions the transnational body as the body-in-motion, vacillating between and across homes and time, and whose title I have borrowed from in formulating this argument. I would argue that these performances of the body-in-motion are symbolic of an emerging "trans" aesthetic, that is at once transnational, transgendered, in transit, and critically transgressive. Bornstein (1994) provides a foundation for this "trans" aesthetic when she argues that, "a fluid identity, incidentally, is one way to solve problems with boundaries. As a person's identity keeps shifting, so do individual boarders and boundaries. It's hard to cross a boundary that keeps moving" (52).

\subsection{Conclusion}

Luka's performance at Colour Me Drag represents more than "claiming space" for new and/or other(ed) queer identities. It is transgressive in its liminality, signaling the ambivalence, fluidity, and negotiability of culturally inscribed boarders. As Bhabha (1994) argues, "Counter-narratives of the nation that continually evoke and erase its totalizing boundaries - both actual and conceptual - disturb those ideological manoeuvres through which 'imagined communities' are given essentialist identities" (149). It is important to note that, any politically subversive identity performance is also necessarily discursive in its political essence, and will therefore always redraw new boundaries. While Luka's performance does challenge and problematize the boundaries of belonging, it does not eradicate these boundaries altogether. If boundaries are constantly being redrawn, then this also means that they are constantly in negotiation, that they are fluid and not fixed. Luka's performance is precisely this negotiation. In pointing to, "community as political designation, as political problem, as something that must be worked, and as something more" (Walcott 2006, 126), Luka's performance is an 
important site of resistance to the webs of power that continually "make" the queer community as a singular and bounded community. Luka's performance sits in contest to assumptions of solidarity and acts of speaking for others that are embodied in mainstream queer politics, as represented in the "You Belong" billboard. As Hall (1992b) argues, the essentialization of identities is no longer politically useful. It is important to look to the liminal spaces within the queer community, where new queer identities and strategies of resistance are emerging, claiming space, and negotiating what it means to be queer in Toronto.

\section{Conclusion}

While I do maintain that the goals of social research should not include generalizability, I do think that this discussion of Toronto Pride Week annd Luka's performance does provide some interesting questions and lessons that could be applied in understanding migrant integration and the negotiation of cultural citizenship. The first lesson that we can derive from this research is that social integration is an intensely complicated process. Integration does not happen in a simple, linear fashion, even when the community that one is integrating into mirrors (some aspects of) ones own identity, for example a queer migrant moving into the queer community. Linear narratives of social integration, such as the "two-way street" model, are overly simplistic. These narratives wrongly assume that social integration happens in a relatively similar fashion for all migrants. The discussions presented in the previous two chapters show that processes of social integration are inextricably embedded in hegemonic power relations. Social integration necessarily happens differently for every migrant. Migrants who are situated differently in relation to hegemonic power structures will have different obstacles to 
navigate and negotiate in the process of integrating. A white, heterosexual, economic migrant from Britain will necessarily have a different experience integrating into Canadian society than a racialized, queer refugee from Mexico. Most discussions of the “two-way street" model of integration, including Frideres' (2008) and Stone et. al's (2008) discussions in the book Immigration and Integration in Canada in the TwentyFirst Century, negate any mention of migrants social positionalities. When they do mention any differences between groups of migrants, such as the integration of refugees as opposed to economic migrants, barriers to integration are typically presented as a problem on the migrants "side" of the street, such as language ability or education. While there is no doubt that these barriers contribute to integration, it is important to realize that the biggest barriers to integration are state inscriptions of power and hegemonic power structures within civil society that position some people as citizens and others as outsiders. These power relations permeate Canadian society, affecting even the lowest levels of community integration. The boundaries of belonging will not be redrawn with the simple completion of a government sponsored Language Instruction for New Comers (LINC) course.

The second lesson that can be derived from this research is that identity plays a central role in the social integration process and the negotiation of cultural citizenship. As such, it would be a grave error on the part of researchers and academics to assume that social integration and cultural citizenship could be easily measured or controlled.

Attempts to measure social integration or cultural citizenship, such as those of Frideres (2008) and Stone et. al (2008), are overly simplistic and ignore the subjective experiences of migrants. In order to negotiate belonging, migrants must ask the intensely complicated 
questions of, "Who am I?" and "Where is home?". These are questions that are often taken for granted by those who have never migrated. There is no easy or simplistic way to study or understand belonging. Migrant's stories, for example, as expressed through cultural performances can provide some insight but these stories represent only one part of a series of uneven negotiations embedded in hegemonic power structures and thus are not the whole story. I would argue that Luibhéid's (2008) assertion that queer migrants occupy the space of "impossible subjects" could be extended to all migrants in Canada. How could something as intensely subjective, rooted in emotion, and embedded in power relations as the notion of belonging, ever possibly be measured or represented by numbers, statistics, or generalized rules? Cultural expressions offer quite possibly the only avenue to understanding social integration and belonging with enough depth and complexity.

The third lesson that could be derived from these discussions is that social integration is an always unfinished project. This is because the notion of community, of society itself is always unfinished. It is not useful to imagine that Canadian society, or that the queer community, represent unitary, fixed entities. These are disconnected networks of groups, smaller communities, and individuals that are constantly in a state of negotiation, constantly shifting. As people change, which they inevitably do, so too do communities and so too do societies. These structures, if we can understand them to be structures at all, are constantly shifting, constantly changing shape; they are fluid. What does it mean to integrate into something that is fluid? It means that integration is a negotiation that will always continue. It means that all members of Canadian society, not just migrants, all members of any given community, are constantly negotiating their own 
integration and sense of belonging. If we applied both Friederes (2008) and Stone et. al's (2008) discussions to the Canadian-born, a significant proportion would not meet their "standards" for integration. Stating that integration is a "two-way street", that there are measurable objectives for integration, or that integration should happen within a specific time frame puts impossible demands on migrants who are somehow expected to adapt to an ever-changing, disconnected and ambivalent society.

This research has explored the concepts of social integration, cultural citizenship, and belonging more generally, from the very subjective position of a single migrant. Luka's story, his performance at Pride Week 2009, represent only a series of sometimes contradictory and ambiguous insights into these processes. If social integration is ever to be seriously considered as a social project and not an imposition of power onto migrants by the state and the dominant groups of society, then it is necessary to consider cultural expressions of migrant identity as contributing to society, as affecting integration. These cultural expressions contribute even when they are deemed threatening or challenging to that elusive notion of "Canadian values." By pointing to multiple ambivalences, by positioning the migrant, the transnational, the transgendered, the queer, and the racialized body in motion and in flux, Luka's performance highlights precisely the convoluted and insidious workings of identity, community, and belonging. It challenges totalizing and essentializing discourses that structure some as insiders and others as outsiders, including the discourse of nationalism. By discussing the webs of power, through and by which community is produced, this research has attempted to show how social integration and the negotiation of cultural citizenship are bigger projects than simply a person finding a place to belong. These are the projects that shape society itself. These projects represent, 
not only the negotiation of belonging, but also the impossibility of ever achieving belonging in any absolute sense. 


\section{Appendix 1 - Sample Recruitment Letter}

Day Month, 2009

Dear

My name is Johannah and I am a researcher from Ryerson University. I am writing in regards to your (drag/dance/burlesque/spoken-word/dramatic/other) performance at Toronto Pride Week on June _, 2009. I am currently working on a research study that analyzes performances, such as your own, as acts of "claiming space" for multicultural Queer/LGBTQ identity in the Queer/LGBTQ community in Toronto. My research approaches these performances as acts of citizenship as they are one of many ways that Queer/LGBTQ people who have immigrated to Canada can participate in Canadian public life and make their mark on Canadian society.

I would like to invite you to participate in a study called, "Citizenship Acts: Queer Immigrants Negotiating Belonging and (Re)Writing Identity Through Performances at Pride Week" and to share your experiences as a performer at Toronto Pride, as well as, your knowledge of the Queer/LGBTQ community in Toronto. As a participant you will be asked to complete between two and five, one-hour (approx.) interview sessions over the next month at times that are convenient for you. During these interview sessions you will be asked to discuss and walk-through your performance, explaining your thought process in planning your performance, as well as, the experience of performing itself. You will also be asked questions about your experiences at Toronto Pride Week more generally, including your first time at Toronto Pride Week as a comparison to your experience performing. There will be no financial or other award or compensation for your participation, but the knowledge and experiences you share will add to a growing body of research on performance art as an act of "cultural citizenship" and will allow people to understand some of the contributions Queer/LGBTQ immigrants have made to the Queer/LGBTQ community in Canada. Your choice to participate or not is voluntary and will not affect any of your existing or future relationships with Ryerson University.

Thank you very much for your time and consideration. If you would like to participate, please contact me by e-mail at Johannah.black@arts.ryerson.ca or by telephone at

Sincerely,

Johannah May Black

Johannah.black@arts.ryerson.ca

Masters Candidate

Immigration and Settlement Studies

Ryerson University 


\section{Appendix 2 - Interview Schedule}

\section{Part A: Getting to know you}

1. How do you identify in regards to sexual orientation and gender? Prompts: Are you comfortable with these identifications or do you prefer not using "labels", explain? Do you find it easy or difficult to fit within these labels, explain? If you consider either your gender or sexuality to be more "fluid", how do you express this in your performance at Pride Week?

2. Before you immigrated to Canada, what country did you live in?

Prompts: How long have you been in Canada? How old were you when you immigrated? How do you identify ethnically/racially? Do you consider yourself more "Canadian" or more (Country of Origin), or do you see them as equal parts of your identity?

3. When did you start performing (drag/dance/spoken word/drama/other)? Prompts: What do you enjoy most about performing?

\section{Part B: General Experiences at Toronto Pride Week}

4. Could you share with me, your first experience at Pride Week in Toronto? Prompts: Who did you go with? What events did you attend? Was this a new experience for you? Where you more comfortable at some events than others?

5. How does that experience compare to your experiences now as a performer at Pride Week?

Prompts: Do you feel like you are a part of a queer community? What impact do you think your performance has in the overall event? How do you think people connect with your performance? Can you think of a metaphor that describes how you fit into, or don't fit into, the queer community?

\section{Part C: Your Performance}

6. Why did you decide to start performing at Price Week?

Prompts: Did you perform at other venues prior to performing at Pride? When was the first time you performed at Pride? Were you asked to perform, did your friends/fans encourage you, or did you decide on your own?

7. Could you walk me through your performance, explaining what you consider to be the meaning behind it as you go?

Prompts: Why did you choose that particular music/costume/dance style/prop etc...? If you were to read "between-the-lines" of your performance, what messages do you think you would find? Is there a political meaning to your performance? If you had to choose, what would you say is the most important part of your performance? Could you explain any metaphors you use in your performance? 
8. Could you tell me about some of the artists and performers that inspire your work as a performer?

Prompts: What do you think the messages are behind this person(s)' work? In what ways is the message in your performance similar or different?

9. Who do you think is your main audience? Or which audience is most important to you?

Prompts: Do you feel that you reach the audience you intend to reach or a different one altogether? Who is most affected by your performance? How do audience members react to your performance?

10. Out of the following photographs taken during your performance, which one do you think best symbolizes the main theme of your performance?

Prompts: What is the main theme of your performance? Why do you like this photo better than some of the others? If this photo were the first thing a person were to see before seeing your performance, what do you think their reaction would be? What aspects of your queer identity do you think are visible or invisible in this photo? What aspects of your ethnic identity do you think are visible or invisible in this photo? What aspects of your identity as a "Canadian" do you think are visible or invisible in this photo?

\section{Part D: Getting Theoretical}

11. How do you think your performance connects you to the home you left in (country of origin) and your home here in Canada?

Prompts: Do you ever perform in the broader ethnic community that you are from? How does your identity as a queer person interact with your ethnic identity and interact with your Canadian identity through your performance? What do you think it means to be queer and (ethnicity)? How do you express this in your performance?

12. What do you think your performance means in Canadian society or culture? Prompts: Do you feel as though you have contributed to Canadian society or culture with your performance? Imagine that there is such thing as the "average Canadian", how do you think they would view your performance? How do you think you have contributed to the queer community or queer culture in Canada? Imagine that there is such a thing as the "average queer Canadian", how do you think they would view your performance?

13. Some people say that "visibility" is important for marginalized groups to gain equal status, others say that it is a trap that leads to the dominant group taking-on marginalized identities or fetishizing marginalized people, what do you think? Prompts: In general do you feel that queer (ethnicity) have visibility in the queer community/Canada? Do you think your performance contributes to the visibility of this group? When you are performing how does visibility "feel", is it painful, satisfying, both, or something entirely different? 


\section{Appendix 3 - Study Overview}

\section{Citizenship Acts: Queer Immigrants Negotiating Belonging and (Re)Writing Identity Through Performances at Pride Week}

\section{Study Abstract}

The broader goal of this research is apply queer theory to the cultural narrative of immigration in order to confuse, destabilize and complicate our pre-conceived notions about what it means to "belong" to a given community or society, what it means to cross borders, and what it means to be "Canadian". To accomplish this, my research will focus specifically on the experiences of queer immigrants to Toronto, Canada, as they negotiate their place in Toronto's queer community(ies).Particular attention will be given to the ways that queer immigrants are contesting the boundaries to the queer community and challenging queer identity constructs through their participation in queer community events, mainly Pride Week 2009. The performances of queer immigrants at Pride Week 2009 will be examined as conscious acts of "claiming space" in the queer community that create visibility for alternative queer identities. Potential participants will be selected because of their public and scheduled performances at Pride Week 2009. In order to gain a nuanced understanding of intersecting identities and community belonging, my research will focus on a series of in-depth, semi-structured interviews with one participant. My research will be grounded in feminist and queer epistemologies, which involve a careful analysis of power dynamics between researcher and participant(s), in order to resist recreating oppressive power structures through the discursive creation of knowledge. The potential benefits to my research will be a nuanced and complicated understanding of the subjective and (sometimes) emotional experiences of using performance to "claim space" and resist narrow identity constructs. The participant will also be given the opportunity to read and make comments to the finished product before it is submitted to insure that any information they are uncomfortable sharing can be altered if they so desire.

\section{Research Questions}

1. Can politically minded performances, focusing on the intersections of queer and immigrant or racialized identities, can act discursively to subvert narrow socially constructed notions of queer identity?

2. Can these same performances can be understood as acts of cultural citizenship that work to rewrite or challenge the borders of the imagined queer community? 


\section{References}

Adler, Sy and Johanna Brenner, (2005) "Gender and Space: Lesbians and Gay Men in the City," In Urban Sociology, eds. Jan Lin and Christopher Mele. London: Routledge, 200-207.

Alcoff, Linda and Elizabeth Potter (1993). "Introduction" In Feminist Epistemologies, eds. Linda Alcoff and Elizabeth Potter. New York: Routledge, 1-20.

Anderson, Benedict (1983). Imagined Communities: Reflections on the Origin and Spread of Nationalism. London: Verso.

Andrew, C., M. Gattinger, M.S. Jeanotte, and W. Straw eds. (2005). Accounting For Culture: Thinking Through Cultural Citizenship. Ottawa: University of Ottawa Press.

Anisef, Paul and Michael Lanphier (2003). The World In A City. Toronto: University of Toronto Press.

Anzaldúa, Gloria (1987). Borderlands, La Frontera: The New Mestiza. San Francisco: Aunt Lute Books.

Austin, J. L. (1962). How to do Things with Words. New York: Oxford University Press.

Bannerji, Himani (2000). The Dark Side of the Nation: Essays on Multiculturalism, Nationalism, and Gender. Toronto: Canadian Scholars Press.

Bauder, Harald (2008). "Citizenship as Capital: The Distinction of Migrant Labour." Alternatives 33:315-333.

Bell, David, Jon Binnie, Julia Cream and Gill Valentine (1994). "All Hyped Up and No Place To Go." Gender, Place, and Culture: A Journal of Feminist Geography 1:1,31-47.

Benhabib, Seyla (2002). The Claims of Culture: Equality and Diversity in the Global Era. Princeton: Princeton University Press.

Bérubé, Allan (2007). "How Gay Stays White and What Kind of White it Stays," In Race and Racialization: Essential Readings, eds. Tania Das Gupta et. al. Toronto: Canadian Scholars' Press Inc., 363-371.

Betancourt, Gerardo (2009). “The Intersections of Gender, Sexuality, Race and Class in Migrants Everyday Lives." Presentation at CERIS Graduate Student Conference, Toronto, ON.

Bhabha, Homi K. (1994) The Location of Culture. London: Routledge. 
Biles, John, Meyer Burnstein, and James Frideres eds. (2008). Immigration and Integration in Canada in the Twenty-First Century. Kingston, ON: Queens University, School of Policy Studies, in partnership with Metropolis.

Bissoondath, Neil (1994). Selling Illusions: The Cult of Multiculturalism in Canada. Toronto: Penguin Books.

Bornstein, Kate (1994). Gender Outlaws. New York: Routledge.

Bourdieu, Pierre (1984). Distinction: A Social Critique of the Judgement of Taste. London: Routledge.

Brah, Avtar (1996). Cartographies of Diaspora: Contesting Identities. London: Routledge.

Bramadat, Paul A. (2001). "Shows, Selves and Solidarity: Ethnic Identity and Cultural Spectacles in Canada." Commissioned by the Department of Canadian Heritage for the Ethnocultural, Racial, Religious, and Linguistic Diversity and Identity Seminar. Halifax: Metropolis. Retrieved August 20, 2009 from http://canada.metropolis.net/events/ethnocultural/publications/shows shelves.pdf.

Butler, Judith (1990). Gender Trouble: Feminism and the Subversion of Identity. London: Routledge.

----- (1997). Excitable Speech: A Politics of the Performative. New York: Routledge.

------ (2004). Undoing Gender. New York: Routledge.

Case, Sue-Ellen (2009). Feminist and Queer Performance: Critical Strategies. New York: Palgrave Macmillan.

Castles, Stephen (2002). "Migration and Community Formation Under Conditions of Globalization.” The International Migration Review 36:4, 1143-1168.

Castles, Stephen and Mark J. Miller (2003). The Age of Migration, $3^{\text {rd }}$ ed. New York: Guilford.

Central Toronto Youth Services (2009). "Ensemble Cast.” Gender Play 2009: Wake. [Brochure].

Chang Hall, Lisa Kaheleole (1993). "Bitches in Solitude: Identity Politics and the Lesbian Community,” In Sisters, Sexperts, Queers: Beyond Lesbian Nation, ed. Arlene Stein. New York: Penguin Books, 218-29. 
Citizenship and Immigration Canada (2009). "Facts and Figures 2008." Citizenship and Immigration Canada. Retrieved August 20, 2009, from http://www.cic.gc.ca/english/resources/statistics/facts2008/permanent/02.asp.

Code, Lorraine (1993). “Taking Subjectivity into Account” In Feminist Epistemologies, eds. Linda Alcoff and Elizabeth Potter. New York: Routledge, 21- 48

Collins, Patricia Hill (1990). Black Feminist Thought: Knowledge, Consciousness, and the Politics of Empowerment. Boston: Unwin Hyman.

Daly, Kerry (1997). "Re-Placing Theory in Ethnography: A Post-Modern View." Qualitative Inquiry 3:3, 343-365.

Decana, Carlos Ulises (2008). “Tacit Subjects." GLQ: A Journal of Lesbian and Gay Studies 14:2-3, 339-359.

Delanty, G. (2002). “Two Conceptions of Cultural Citizenship: A Review of Recent Literature on Culture and Citizenship." The Global Review of Ethnopolitics 1:6066.

Derrida, Jacques (1974). Of Grammatology, trans. Gayatri Spivak. Baltimore: Johns Hopkins University Press.

DeVault, Marjorie L. and Glenda Gross (2007). "Feminist Interviewing: Experience, Talk and Knowledge." In Handbook of Feminist Research: Theory and Practice, ed. Sharlene Nagy Hesse-Biber. London: Sage Publications, 173-197.

Douglas, Mary (1966). Purity and Danger: An Analysis of the Concepts of Pollution and Taboo. London: Routledge.

Ellis, Sonia J. (2007) "Homophobia, Rights and Community: Contemporary Issues in the Lives of LGB people in the UK," In Out in Psychology: Lesbian, Gay, Bisexual, Transgender, and Queer Perspectives, eds. V. Clarke and E. Peel. Hoboken, NJ: John Wiley \& Sons Ltd..

Escudero-Alías, Maite (2009). Long Live the King: A Genealogy of Performative Genders. Newcastle upon Tyne, UK: Cambridge Scholars Publishing.

Fanon, Frantz (1967). Black Skin, White Masks. New York: Grove Press.

Favell, Adrian (1999). “To Belong or Not to Belong: The Post-National Question,” In The Politics of Belonging: Migrants and Minorities in Contemporary Europe, ed. Andrew Geddes and Adrian Favell. Aldershot, England: Ashgate, 209-227.

Féher, F. and Ágnes Heller (1994). “Naturalisation or 'Culturalisation'?” In From Aliens to Citizens, ed. R. Bauböck. Aldershot, England: Avebury, 135-148. 
Florida, Richard (2005). The Flight of the Creative Class: The New Global Competition for Talent. New York: Routledge.

Frideres, James (2008). "Creating an Inclusive Society: Promoting Social Integration in Canada." In Immigration and Integration in Canada in the Twenty-First Century, John Biles, Meyer Burstein, and James Frideres eds. Kingston, ON: Queens University, School of Policy Studies, in partnership with Metropolis, 77-101.

Frolic, Andrea (2001). "Wear It With Pride: The Fashions of Toronto's Pride Parade and Canadian Queer Identities.” In In a Queer Country: Gay and Lesbian Studies in a Canadian Context, Terry Goldie ed. Vancouver: Arsenal Pulp Press.

Foote, J., and M. Smith (2005). "Framing Indicators of Cultural and Shared Citizenship in Canada." Paper Presented in the Canadian Heritage workshop Cities and Citizenship: Developing Indicators of Cultural Diversity. Toronto: $10^{\text {th }}$ International Metropolis Conference, October 17-21.

Fortier, Anne-Marie (2001). "Coming Home: Queer Migrations and Multiple Evocations of Home." European Journal of Cultural Studies 4:4, 405-424.

Foucault, Michel (1977). "Nietzsche, Genealogy, History.” In Language, Counter Memory, Practice: Selected Essays and Interviews by Michel Foucault, Donald F. Bouchard ed. and Donald F. Bouchard and Sherry Simon trans. Ithaca: Cornell University Press.

----- (1989). "The Subject and Power," In Michel Foucault: Beyond Structuralism and Hermeneutics, eds. H. L. Dreyfus and P. Rainbow. Chicago: University of Chicago Press, 208-228.

Fung, Richard (1991). "Looking for my Penis: The Eroticized Asian in Gay Video Porn." In How Do I Look: Queer Film and Video, ed. Bad Objects-Choices. Seattle: Bay Press.

Gawthrop, Daniel (2005). The Rice Queen Diaries: A Memoir. Vancouver: Arsenal Pulp Press.

Gay Asians Toronto (1996). CelebrAsion: Shared Lives: An Oral History of Gay Asians. Toronto: Gay Asians Toronto.

Gilroy, Paul (2000). Between Camps. Nations, Cultures and the Allure of Race. London: Penguin Press.

Glick, B. (1999). "Reflections on Oral History in the New Millennium: Roundtable Comments." The Oral History Review 26:2, 1-17. 
Goldstein, Linda (1997). "Getting into Lesbian Shorts: White Spectators and Performative Documentaries by Makers of Colour." In Between the Sheets, In the Streets: Queer, Lesbian, Gay Documentary, eds. Chris Holmlund and Cynthia Fuchs. Minneapolis: University of Minnesota, 175-189.

Graham, Neil and Derreck Roemer dir. (2007). The Last Call at the Gladstone Hotel. Toronto: Last Call Productions.

Guo, Shibao (2008). "The Promotion of Minority Group Rights as the Protection of Individual Rights and Freedoms for Immigrants: A Canadian Case Study." Interchange 39:2, 259-275.

Halberstram, Judith (1998). Female Masculinity. London: Duke UP.

Hall, Stuart (1980). "Encoding/Decoding." In Culture, Media, and Language: Working Papers in Cultural Studies, eds. Stuart Hall, D. Hobson, A. Lowe and P. Willis. London: Hutchinson, 128-139.

----- (1992a). “The West and the Rest: Discourse and Power.” In Formations of Modernity, eds. Stuart Hall and Bram Gieben. Cambridge: Polity Press, 275-331.

----- (1992b). "What is This 'Black' in Black Popular Culture?” In Black Popular Culture, ed. G. Dent. Seattle, WA: Bay Press, 21-35.

Hammers, Corie (2008). "Bodies That Speak and the Promises of Queer: Looking to Two Lesbian Bathhouses for a Third Way." Journal of Gender Studies 17:2, $147-64$.

Harding, Sandra (1993). "Rethinking Standpoint Epistemology: What is 'Strong Objectivity'?” In Feminist Epistemologies, eds. Linda Alcoff and Elizabeth Potter. New York: Routledge, 42-89.

Hesse-Biber, Sharlene Nagy ed. (2007). Handbook of Feminist Research: Theory and Practice. London: Sage Publications.

hooks, bell (2000). "Changing Perspectives on Power.” Feminist Theory: From Margin to Centre. Cambridge, MA: South End Press, 84-95.

Inda, Jonathan X. and J. K. Aguire (1998). "Transnational Migrant, Cultural Citizenship, and the Politics of Language in California." Educational Policy 12:6, 659-81. (2000) "Performativity, Materiality, and the Racialized Body", Latino Studies Journal 11:3, 74-99.

Keil, Roger and Kurt Hubner (2005). "Introduction to a Debate on Migration, Diversity, Multiculturalism, Citizenship: Challenges for Cities in Europe and North America." International Journal of Urban and Regional Research 29:3, 641-643. 
Kelly, Ninette and Michael Trebilcock (1998). The Making of the Mosaic: A History of Canadian Immigration Policy. Toronto: University of Toronto Press.

Kuhr, Fred (2009). “Unstoppable: 2009's Grand Marshals \& Honoured Groups.” Xtra 643: June 18, 2009, 20.

Kuntsman, Adi (2007). "Hospitality in Flames: Queer Immigrants and Melancholic Be/longing," In Mobilizing Hospitality: The Ethics of Social Relations in a Mobile World, eds. Jennie German Molz and Sarah Gibson. Burlington, VT: Ashgate, 145-57.

Kymlicka, Will (1995). Multicultural Citizenship. Oxford: Oxford University Press.

Leap, William (2007). "Language, Socialization, and Silence in Gay Adolescence," In Sexualities \& Communication in Everyday Life, eds. Karen E. Lovass and Mercilee M. Jenkins. Thousand Oaks, CA: Sage Publications, 95-106.

Li, Peter S. (2003). Destination Canada: Immigration Debates and Issues. Don Mills, ON: Oxford University Press.

Lincoln, Yvonna S. (1995). "Emerging Criteria for Quality in Qualitative and Interpretive Research.” Qualitative Inquiry 1, 275-289.

Lloyd, Moya (1999). "Performativity, Parody, Politics.” Theory, Culture and Society. $16: 2$.

Lorde, Audre (1984). Sister Outsider: Essays and Speeches. Freedom, California: The Crossing Press.

Luibhéid, Eithne (2008). "Queer/Migration: An Unruly Body of Scholarship.” GLQ: A Journal of Lesbian and Gay Studies 14:2-3, 169-424.

Manalansan, Martin F. (1997). "In the Shadows of Stonewall: Examining Gay

Transnational Politics and the Diasporic Dilemma," In Politics in the Shadow of Capital, eds. Lisa Lowe and David Lloyd. Durham, NC: Duke University Press, 485-505.

(2003). Global Divas: Filipino Gay Men in the Diaspora. Durham, NC: Duke University Press.

Marx, Karl and Friedrich Engels (1976). "The Ruling Class and the Ruling Ideas.” In Collected Works, trans. Richard Dixon. New York: International Publishers, 5962 .

Mercer, Colin (2002). Towards Cultural Citizenship: Tools for Cultural Policy and Development. Hedmore, Sweden: Bank of Sweden Tercentenary Foundation and Gidlungs Forlag. 
Mercer, Kobena (1994). Welcome to the Jungle: New Positions in Black Cultural Studies. New York: Routledge.

------ (1996). “Decolonization and Disappointment: Reading Fanon's Sexual Politics.” In The Fact of Blackness: Frantz Fanon and Visual Representation, ed. Alan Read. Seattle: Bay Press, 114-130.

Miller, T. (2002). “Cultural Citizenship.” In A Handbook of Citizenship Studies, E.R. Isin and B.S. Turner eds. London: Sage.

Mohanraj, Mary Anne (2006). Bodies in Motion. New York: Harper Collins.

Mulvey, Laura (1975). “Visual Pleasure and Narrative Cinema.” Screen 16:3, 22-34.

Muñoz, José Esteban (1999). Disidentifications: Queers of Colour and the Performance of Politics. Minneapolis: University of Minnesota Press.

Nash, Catherine Jean (2005). “Toronto's Gay Villiage (1969-1982): Plotting the Politics of Gay Identity.” The Canadian Geographer 50:1, 1-16.

Oakley, Ann (1991). "Interviewing Women: A Contradiction in Terms.” In Doing Feminist Research, ed. H. Roberts. London: Routledge, 30-61.

Ong, Aihwa (1993). "On the Edges of Empires: Flexible Citizenship Among Cosmopolitan Chinese." Positions 1:745-78.

----- (1999). "Cultural Citizenship as Subject Making: Immigrants Negotiate Racial and Cultural Boundaries in the United States." In Race, Identity, and Citizenship, eds. Rodolfo D. Torres, Louis F. Mirón, and Jonathan Xavier Inda. Oxford: Blackwell Publishers, 262-294.

O’Shaughnessy, John (2004). Persuasion in Advertising. London: Routledge.

Patai, Daphne (1991). "U.S. Academics and Third World Women: Is Ethical Research Possible?” In Women's Worlds: The Feminist Practice of Oral History, eds. S. B. Gluck and Daphne Patai. New York: Routledge, 137-153.

Peesker, Saira (2009). "Toronto's other gaybourhood shows its stripes with Queer West Fest." CP24 News. Toronto: CP24 News, June 17 ${ }^{\text {th }}, 2009$. Retrieved August 20, 2009, from http://www.cp24.com/servlet/an/local/CTVNews/20090616/090616 queer fest/2 0090617/?hub=CP24Entertainment. 
Pendleton Jiménez, Karleen (2005). "Lengua Latina: Latina-Canadians (Re)constructing Identity Through a "Community of Practice," In Learning, Teaching \& Community: Contributions of Situated and Participatory Approaches to Educational Innovation, eds. C. Pease-Alvaraez \& S. Schecter. Mahwah, NJ: Lawrence Erlbaum Associates, Inc.

Phelan, Shane (1994). “Getting Specific About Community," in Getting Specific: Postmodern Lesbian Politics. Minneapolis: University of Minnesota Press, 76-97.

Podmore, Julie (2000). "Lesbians in the Crowd: Gender, Sexuality and Visibility Along Montreal's Boul. St-Laurent." Gender, Place and Culture 8(4): 333-335.

Poore, Grace (1996). “Three Movements in A Minor: Lesbians and Immigration.” Off Our Backs 26:8, 14.

Pride Toronto (2009). 2009 Official Pride Guide. [Brochure].

Razack, Sherene (2002). Race, Space, and the Law: Unmapping A White Settler Society. Toronto: Between the Lines.

Rosaldo, Renato (1994). “Cultural Citizenship in San José, California.” Polar 17: 57-63. (1999). “Cultural Citizenship, Inequality, and Multiculturalism.” In Race, Identity, and Citizenship, Rodolfo D. Torres, Louis F. Mirón, and Jonathan Xavier Inda eds. Oxford: Blackwell Publishers, 253-261.

Ross, Becki (2002). "Book Review: Taking it Off, Putting it On: Women in the Strip Trade by Chris Bruckert." Canadian Journal of Women and the Law 15: 378-382.

Roy, Sandip (1998). "The Call of the Rice: (South) Asian American Queer Communities." In A Part, Yet Apart, Lavinia Dhingra Shankar and Rajini Sirkanth eds. Philadelphia: Temple University Press, 168-85.

Sears, Alan (2005). "Queer Anti-Capitalism: What's Left of Lesbian and Gay Liberation?" Science and Society 69:1, 92-112.

Secomb, Linnell (1997). "Queering Community." Queerzone. Nepean: University of Western Sydney Women's Research Centre, 9-16.

Shafir, Gershon (1998). “Introduction: The Evolving Tradition of Citizenship.” In The Citizenship Debates, ed. S. Gershon. Minneapolis: Minneapolis University Press.

Silvera, Makeda (1990). "Man Royals and Sodomites: Some Thoughts on the Invisibility of Afro-Caribbean Lesbians." In Lesbians in Canada, ed. Sharon Dale Stone. Toronto: Between the Lines, 48-60. 
Sinfield, Alan (2000). "Diaspora and Hybridity: Queer Identity and the Ethnicity Model." In Diaspora and Visual Culture: Representing Africans and Jews, ed. N. Mirzoeff. London: Routledge, 95-114.

Smith, Dorothy (1999). Writing the Social. Critique, Theory, and Investigation. Toronto: University of Toronto Press.

Stone, Marjorie, Hélène Destrempes, John Foote, and M. Sharon Jeannotte (2008). "Immigration and Cultural Citizenship: Responsibilities, Rights, and Indicators." In Immigration and Integration in Canada in the Twenty-First Century, John Biles, Meyer Burstein, and James Frideres eds. Kingston, ON: Queens University, School of Policy Studies, in partnership with Metropolis, 103-135.

Sullivan, Nikki (2003). A Critical Introduction to Queer Theory. New York: New York University Press.

Valentine, Gill (1989). “The Geography of Women's Fear.” Area, 21:385-90.

Valverde, Marianne (2006). "The Respectable Same-Sex Couple: A New Entity in the History of Sexuality." Feminist Studies 32:1, 155-62.

Volcano, Del LaGrace and Judith Halberstam (1999). The Drag King Book. London: Serpent's Tail.

Walcott, Rinaldo (2006). "Black Men in Frocks: Sexing Race in a Gay Ghetto (Toronto)," In Claiming Space: Racialization in Canadian Cities, ed. Cheryl Teelucksingh. Waterloo, ON: Wilfred Laurier University Press, 121-133.

Wark, McKenzie (1997). "Fuck Diversity." Queerzone. Nepean: University of Western Sydney Women's Research Centre, 6.

Watney, Simon (1988). Policing Desire: AIDS, Pornography, and the Media. Minneapolis: University of Minnesota Press.

Williams, R. (1976). Keywords: A Vocabulary of Culture and Society. Fontana: Croom Helm.

Wolf, Deborah (1980). The Lesbian Community. Berkeley, CA: University of California Press.

Wray, B. J. (2000). "Choreographing Queer: Nationalism, Citizenship, and Lesbian Dance Clubs." In Dancing Bodies, Living Histories: New Writing About Dance and Culture, eds. Lisa Doolittle and Anne Flynn. Banff, Alta: Banff Press Centre, 22-47. 
Young, Iris Marion (1986). "The Ideal of Community and the Politics of Difference." Social Theory and Practice 12:1, 1-26.

Young, Lola (1996). "Missing Persons: Fantasizing Black Women in Black Skin, White Masks.” In The Fact of Blackness: Frantz Fanon and Visual Representation, ed. Alan Read. Seattle: Bay Press, 86-100.

Yuvall-Davis, Nira (1997) Gender and Nation. London: Sage.

(1999) "Multi-Layered Citizenship and the Age of 'Glocalization'." International Feminist Journal of Politics 1:1, 119-137.

(2006) "Belonging and the Politics of Belonging." Patterns of Prejudice 40:3, 197214. 